\title{
Fiscal Policy in NeW EU Member States Go EAST, PRUDENT MAN!
}

\author{
ONDŘEJ SCHNEIDER \\ JAN ZÁPAL
}

CESIFO WORKING PAPER NO. 1486

CATEgORY 1: Public FinANCE

JUNE 2005

\footnotetext{
An electronic version of the paper may be downloaded

- from the SSRN website:

www.SSRN.com

- from the CESifo website:

www.CESifo.de
} 


\title{
Fiscal Policy in New EU Member States Go EAST, PRUDENT MAN!
}

\begin{abstract}
The European Union (EU) accepted ten new member states (NMS) in 2004. These countries, mostly former socialist countries, have had to adjust their economic policies to the EU's standards. Perhaps most difficult has proven to be fiscal policy whereby NMS must comply with the Stability and Growth Pact (SGP) rules. Indeed, six out of the ten NMS have breached the SGP limits and were put in Excessive Deficit Procedure (EDP). While the SGP is being modified, fiscal policy is set to remain on the agenda for all NMS in years to come.

In this paper, we analyze fiscal policy in the NMS, focusing primarily on the time period that immediately preceded their EU accession. We analyse the structure and scale of these countries' fiscal policy and identify main trends in revenues and expenditures of their public budgets. We then explore dynamics of fiscal policy in the new member states and isolate main factors of the dynamics. Namely, we show how much of the consolidations was due to the fiscal authorities' effort and how much was caused by external factors. We also show that most NMS governments have run a rather inconsistent fiscal policy and have not consolidated their budgets appropriately by postponing politically difficult consolidation measures. However, we also identify a group of countries characterised by strong reform efforts and responsible fiscal policy-making, supported usually by strong economic growth. In this context, room is given to economic, as well as political economy factors.
\end{abstract}

JEL Code: E6, E62, H2, H6, H87.

Keywords: fiscal policy, new member states, consolidations, Stability and Growth Pact, Excessive Deficit Procedure, growth accounting, probit analysis.

\author{
Ondřej Schneider \\ Institute of Economic Studies \\ Charles University, Prague \\ Faculty of Social Sciences \\ Opletalova 26 \\ 11001 Prague 1 \\ Czech Republic \\ schneider@fsv.cuni.cz
}

\author{
Jan Zápal \\ Institute of Economic Studies \\ Charles University, Prague \\ Faculty of Social Sciences \\ Opletalova 26 \\ 11001 Prague 1 \\ Czech Republic
}

We are grateful to Professor Jan Winiecki who initiated this research. We would also like to thank following people for providing us with helpful comments, suggestions and documents: Marek Mora of European Commission; Martin Gregor of the Charles University; and Milena Horčicová and Drahomíra Vašková of the Czech Finance Ministry. Our thanks also to CESifo, Munich for the hospitality and encouragement. All remaining errors are the authors' responsibility. 


\section{INTRODUCTION}

Fiscal policy remains one of the most intriguing fields of economic theory and policy. The economic theory, in particular, stresses that fiscal policy is better conducted within a framework of ex-ante defined rules. However, real world policy-makers still seem happy to ignore this conclusion and prefer discretion to rules. Nowhere is this gap as visible as in the group of countries that have just become members of the European Union (EU). ${ }^{1}$ These countries run fiscal policy that is torn between (apparent) needs of the society still suffering from the transition-associated costs and used to high social transfers and rather rigid and demanding rules for fiscal policy within the EU. The NMSs cope with these demands in strikingly different ways and with very uneven results. We try to analyse roots and reasons of this diversity of the NMSs' fiscal policies.

The paper discusses the apparent emergence of two groups within the NMSs with respect to fiscal policy. Six out of the ten NMSs have not managed to cut their general government deficits ${ }^{2}$ below $3 \%$ of GDP and thus has been found to violate prescripts of Stability and Growth Pact (SGP) and has been subsequently put under Excessive Deficit Procedure (EDP) in July 2004. Four countries, on the other hand, fare rather well vis-à-vis the SGP rules and have very low government debts. We try to answer the intrigue question what had made the authorities in the first group to ignore the well-known fact that they would be required to comply with $\mathrm{SGP}^{3}$

To that end, the paper analyses in what aspects do NMSs differ in composition of the revenue and expenditure sides of the budget and what main determining factors have shaped their fiscal policy. Second, the paper compares fiscal policy in NMSs to fiscal policy in old EU member states (EUR-15). Third, we identify major reforms that have already been concluded in NMS and analyse in what respect experience of EUR-15 applies to NMSs. Throughout our work, we focus predominantly, though not exclusively, on the time period 2001 through 2004, i.e. on time period which immediately preceded NMSs' EU accession.

It is fair to acknowledge, that any attempt to analyse fiscal policy is bound to be limited by several challenges. The most acute challenge concerns the accessibility of reliable data, which would span for reasonably long period enabling us to identify main trends of fiscal policy in NMSs and at the same time would have appropriate structure with respect to main revenue and expenditure aggregates of NMSs' budgets. For this reason we rely on the data from European Commission (2004b) which span from early 1990's till 2006. The

${ }^{1}$ The ten NMS are Cyprus (CY); Czech Republic (CZ); Estonia (EE); Hungary (HU); Latvia (LV); Lithuania (LT); Malta (MT); Poland (PL); Slovenia (SI); and Slovakia (SK). All became members of the European Union in May 2004 and we will call them throughout the paper New Member States (NMSs). Only Cyprus and Malta had not been members of the socialist, Soviet-run system that collapsed in 1989.

${ }^{2}$ In what follows, when we refer to government, we mean always general government.

${ }^{3}$ All NMSs with respect to SGP are classified as "member states with derogation", which means that those countries are expected to comply with SGP limits for government budget deficit of $3 \%$ GDP and government debt of $60 \%$ of GDP. Although they can not be fined for breaching those limits, they are put under EDP and subsequent intensified fiscal surveillance process and can be prohibited to draw financial resources from EU Cohesion Fund (see European Commission (2004a), pp. 69-72, for details). Awareness of NMSs of the fact that they would be obliged to comply with SGP rules is apparent from Pre-Accession Economic Programmes for year 2001. 
predicted values for 2005 and 2006 are based on the European Commission's (EC) forecasts that are based, in turn, on fiscal plans submitted by member states. Data used in this paper are based on autumn 2004 governments' fiscal notifications and therefore for year 2004 present expected values and for years 2005 and 2006 present predictions of EC.

Bearing all the qualifications in mind, we proceed as follows. In the next part, we discuss more closely position of NMSs at the beginning of the accession process and we identify two distinct groups within the NMS. In the third part, we present some stylized facts about NMSs public budgets, their expenditure and revenue structure and dynamics and about budget deficits and government debts in those countries. In the fourth part, we look more closely on the underlying forces that contributed to reduction (or expansion) in budget deficits in NMSs, using growth accounting technique pioneered by Hagen, Hallett and Strauch (2001). We also analyse to what extent the NMS have run a countercyclical fiscal policy. The fifth part analyses politics of fiscal consolidations and the following section investigates into more detail periods of fiscal consolidations in NMSs. Seventh part concludes the paper by presenting some insights from the EUR-15 pre-euro adoption period.

\section{FISCAL POLICY'S MAIN PATTERNS IN THE NMSs}

While often taken as a homogenous group, it is fair to acknowledge that the NMSs started from a very different set up. Some countries were free of any government debt (Estonia, Czech Republic), some had accumulated rather significant debts (Hungary $74 \%$ of GDP, Cyprus more than $60 \%$ ). The NMSs have differed in the conduct of fiscal policy as well. Estonia has never had a bigger deficit than $3,7 \%$ in one exceptional year; similarly Slovenia has crossed the $3 \%$ threshold just once in 2000. Other countries have run much more adventurous fiscal policy: the biggest deficit in the Czech Republic and Slovakia was 12 $\%$ of GDP, $10 \%$ in Malta and $9 \%$ in Hungary - see tables in the appendix.

Perhaps most importantly, though, the ten NMSs differ in the size of their respective governments' budgets. The two groups of countries emerge: Small and Big governments. The group of Small(ish) governments consists of the three Baltic countries (Estonia, Latvia, Lithuania) and Slovakia. The Big governments group consists of the remaining six countries: Central European four (Czech Republic, Poland, Hungary and Slovenia) plus two little Mediterranean islands of Cyprus and Malta. While the former group now (in 2004) spends $36-38 \%$ of their respective GDPs through the government, the latter group is characterised by the government share of $46-52 \%$ in GDP. The gap is thus noticeable and significant - see the chart 1 .

It may be interesting to note that only Slovakia has managed to move from the Big to the Small Government group - see chart 1. Its expenditures fell from $54 \%$ of GDP in 1995 (and even $65 \%$ in 1997, at the height of the Meciar's government) to $38 \%$ now, one of the most pronounced government's shrinkage in history. ${ }^{4}$

\footnotetext{
${ }^{4}$ This remarkable performance remains open to re-interpretations, though. As some papers in this issue argue, the Slovak reforms are far from being concluded and some data are better taken and interpreted carefully.
} 
On the other hand, Cypriot government used to spend about $38 \%$ of the country's GDP in the 1990's, but the share increased to $46 \%$ in 2003. The other Mediterranean island Malta - has shared similar fiscal increase: from about $42 \%$ of GDP to $50 \%$ now.

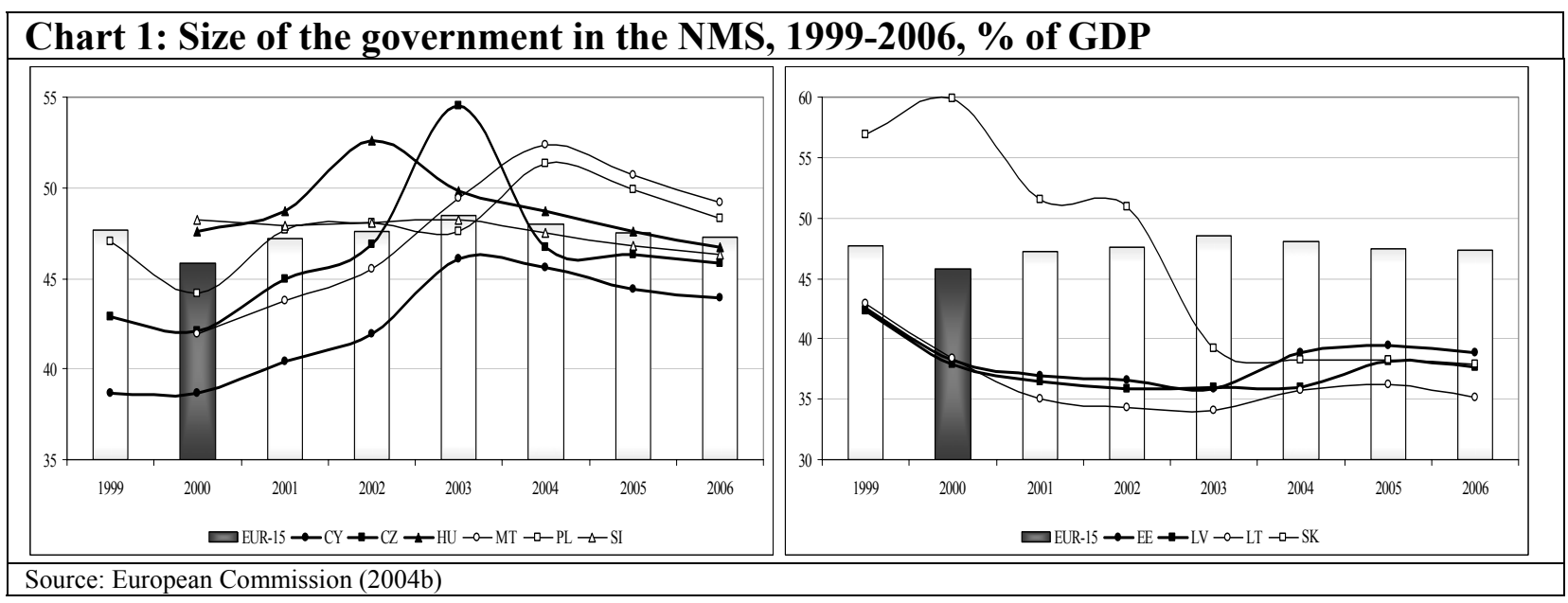

With respect to public budget deficits, the group make-up is only marginally different. The group of Big deficit countries ${ }^{5}$ consists of the same countries as the group of Big governments, only Slovakia substitutes for Slovenia that has moved to the group of countries with deficits within the SGP rules. Slovakia, however, has been approaching the SGP limits rather quickly in recent years. The correlation between low deficit and (relatively) low government expenditures suggests that conduct and quality of fiscal policy does differ between the two groups of countries.

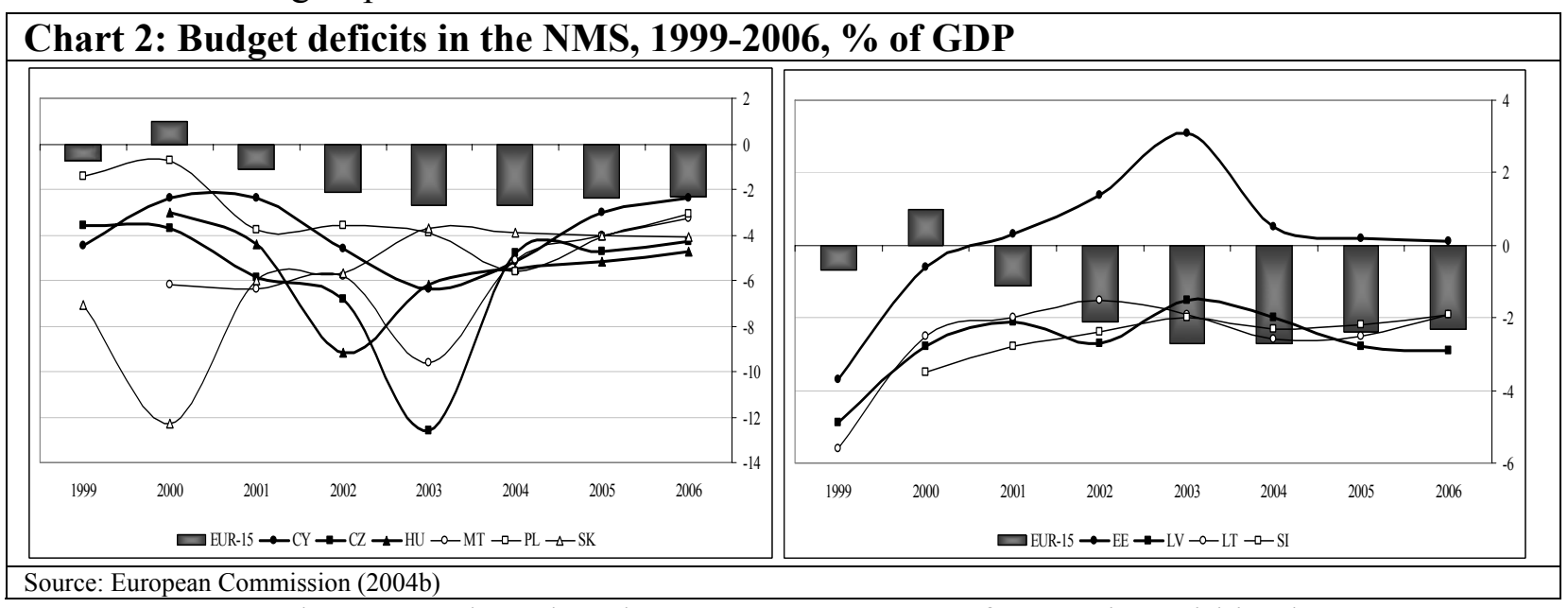

We can, thus, speculate that there are two groups of countries within the ten NMSs. One relies on higher government expenditures and runs more pronounced budget deficits. This group consists of the Czech Republic, Hungary, Poland, Cyprus and Malta. The second group, represented by the three Baltic republics - Estonia, Latvia and Lithuania - is characterised by lower government budget share in GDP and by low budget deficits. The two countries are somewhat between these two groups: Slovenia has high and stable government expenditures, but it still manages to keep its budget deficit under control. Slovakia, on the

${ }^{5}$ We use the deficit criterion in the following chapters, as we denote "EDP countries" or "EDP" for short those countries that have been found to violate SGP and has been put under EDP in July 2004 (Cyprus, Czech Republic, Hungary, Malta, Poland and Slovakia). The second group "non EDP countries" or "non EDP" for short consists of Estonia, Latvia, Lithuania and Slovenia. 
other hand, used to be synonymous with unsustainable fiscal policy, but has turned out to be the most fervour reformer within the NMSs. It has eliminated a substantial part of government expenditures and limited its budget deficits within the reach of the SGP limit of $3 \%$ of GDP.

In the following text, we will use the deficit-based division of the NMS, dividing the NMSs into the "EDP" and "non-EDP" groups. While we lose some information by presenting only average numbers for both groups, this division allows us to make discussion of various fiscal policies manageable. Our division might also seem odd since it is based solely on budget deficit in NMSs in year 2004. However, the very fact that governments in EDP countries were not able to cut their deficits below $3 \%$ of GDP reveals some information about fiscal policy making in EDP countries. However, even when we used the division of NMSs according to the size of the government, our results did not change significantly.

\section{FISCAL POLICY STRUCTURE IN THE NMS's}

This section presents more detailed data on fiscal developments in the NMSs since 1995. The chapter analyses aggregate data on revenues and expenditures, but we also decompose these aggregates as to identify main drivers of fiscal developments. The main features of the decade 1995-2005 are a slow decrease in government expenditures and, even smaller, fall in government revenues in the NMS. The developments have been more volatile in the EDP group of countries that have witnessed shrinkage by about $6 \%$ of GDP both in expenditures and revenues. The non EDP group, on the other hand, has enjoyed more stability and has not changed its relative budget size.

\section{New and old EU members}

First, look in more details on the share of government revenues in GDP in the NMS and in the old EU members (EUR-15). Taken the NMS as one group, the revenue share has declined gradually by about $3 \%$ of GDP since 1995 till 2003 and is expected to increase slightly over next few years, which reflects mainly expected increase in revenues of EDP countries. At the same time, comparison to EUR-15 reveals, that revenue in NMSs has been on average $5 \%$ of GDP lower for the whole period with maximum difference in years 1999 and 2000 given mainly by the exceptional rise of revenues in EUR-15 in the run up to the euro adoption.

Government expenditures in NMSs have also declined gradually since 1995 from $46 \%$ to about $44 \%$ in 2005. Again, comparing NMSs to EUR-15, government expenditures were on average $4 \%$ of GDP lower, with difference somehow higher since beginning of this century which is given by exceptional increase of expenditures in EUR-15.

Development of government expenditures and revenues translated into government budget deficits in NMSs, rising from moderate average of around $2 \%$ of GDP in years 1997 and 1998 to deficits around $4 \%$ of GDP since 2000. As NMSs boosted their expenditures in 2002 , the deficit ballooned to $4,5 \%$ of GDP on average. Thus, NMSs on average do not comply with SGP and their non-compliance has increased almost exactly at the moment of their accession.

Comparing development of government budget deficits in NMSs to development in EUR-15, budget deficit were on average higher in NMSs since 1998 and the difference 
reached its maximum in year 2000, which was the year when government budget deficit remained at about $4 \%$ of GDP in NMSs on the one hand and was the only year since 1995 when EUR-15 governments managed to bring their budgets into surplus on the other.

High deficits in NMSs translated into rising indebtness of those countries, although still relatively low when compared to EUR-15. The average debt increased from less than $30 \%$ in 1996 to $40 \%$ now. The EUR-15 debt, on the other hand, was falling in the mid 1990 's but then stabilised at about $64 \%$ of GDP - see tables in the appendix.

\section{The EDP and non-EDP countries}

We now turn to differences in major fiscal aggregates of the EDP and non EDP countries. As is apparent from the chart 3, government expenditures in EDP countries developed similarly as in the EUR-15. They have oscillated around the level of $46 \%$ of GDP and after increase in years 2000-2003 are expected to decline in the future. On the other hand, government expenditures in non

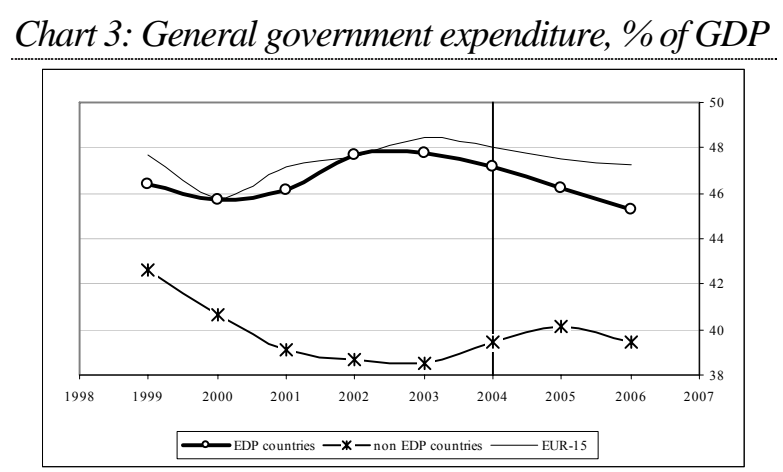

Source: European Commission (2004b) EDP countries have remained approximately $6 \%$ of GDP below the level of expenditures in EDP countries and in contrast to them, declined in the period 2000 through 2003.

As regards government revenues in EDP countries, it remained more or less steady through the last decade at around $42 \%$ of GDP, although there is a jump of $1,5 \%$ of GDP between years 2003 and 2004. Government revenues of EDP countries have been by about $4 \%$ below the EUR-15 level but about $4 \%$ above government revenues in the non EDP countries - see chart 4.

\section{Structure of tax systems}

Concentrating only on major fiscal

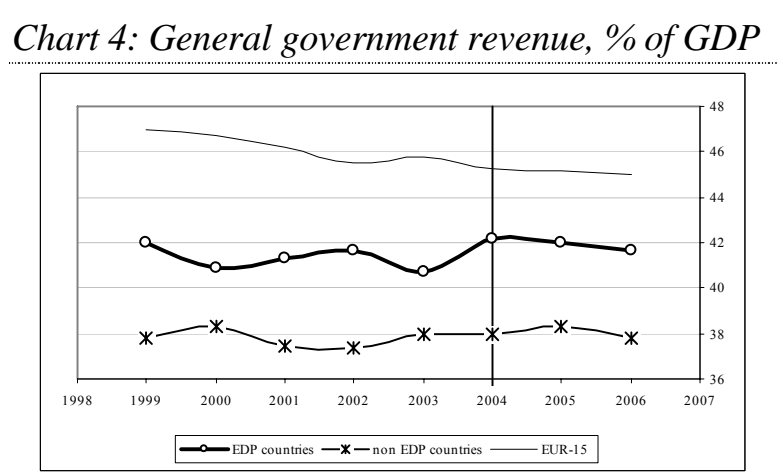

Source: European Commission (2004b) aggregates presents too an inadequate picture of the fiscal policy in NMSs. Therefore we analyse indirect taxation revenues (mainly value added tax (VAT) and specific commodity taxes), direct taxation revenues (mainly corporate income tax (CIT) and personal income tax (PIT)) and social security revenues (mainly contributions to the pension, health and other social insurance systems). 
Judging NMSs according to percentage of their revenues that comes from indirect taxation, it is apparent that until approximately 2002, there has been no significant difference between EDP, non EDP and EUR-15 countries in this respect. Beginning in 2003, EDP countries experienced higher revenue from indirect taxation which climbed above $14 \%$ of GDP, possibly reflecting first attempts of policymakers of EDP countries to cut budget deficit below SGP $3 \%$ of GDP benchmark. On the

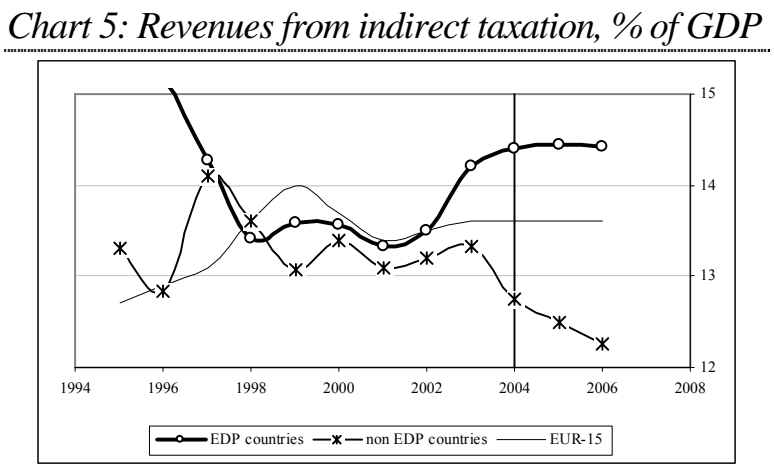

Source: European Commission (2004b) other hand, share of GDP raised through indirect taxation in non EDP countries dropped below $13 \%$ and is expected to decrease in the future. The share of indirect tax revenues in GDP of EUR-15 countries lies between EDP and non EDP countries.

A similar chart 6 shows that NMSs differ significantly from EUR-15 countries in that they rely less on direct tax revenue. While EUR-15 countries raise approximately the same amount from indirect and direct taxes of about $13 \%$ of GDP, EDP as well as non EDP countries collect through direct taxes less than $9 \%$ of GDP, with slightly decreasing trend the over last years. Also, there seems to be no important difference between EDP and non EDP countries with respect to share of GDP raised through direct taxes. ${ }^{6}$

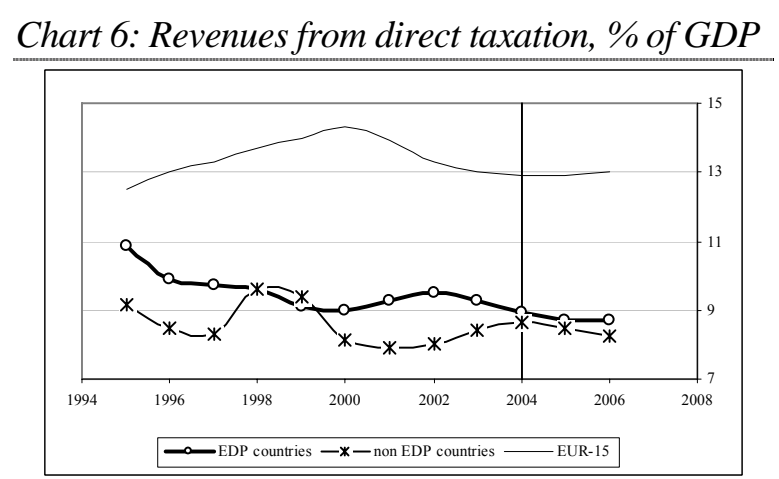

Source: European Commission (2004b)

Social security contributions - a personal income tax in disguise - collect more than $10 \%$ GDP in NMSs and more than $14 \%$ of GDP in EUR-15. Although considerably higher in the second half of 1990s in EDP countries as compared to non EDP countries, social security contributions declined and currently approximate the share in non EDP countries. The contributions, in fact earmarked taxes, are usually collected from labour income and are supposed to finance the social security programs, mainly pay-as-

Chart 7: Revenues from social contributions, \% of GDP

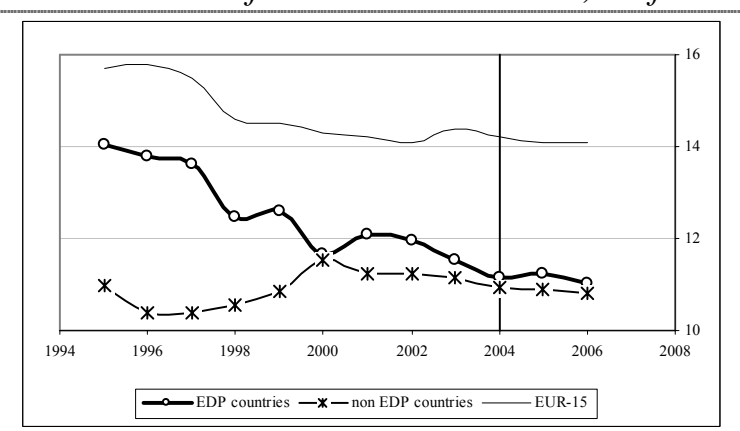

Source: European Commission (2004b) you-go (PAYG) pension systems. It is, thus, politically sensitive that the share of social security contributions have fallen in the EDP countries from $14 \%$ of GDP in 1995 to about $11 \%$ of GDP now.

${ }^{6}$ Government revenues from direct taxes in NMSs have been stable during period since 1995 through 2004 despite the fact, that effective top statutory tax rate on corporate income has declined from average $30,6 \%$ in 1995 to average of $21,5 \%$ in 2004 (see European Commission (2004c) for details). 


\section{Structure of expenditures}

It is a well established fact that what really matters for a successful fiscal consolidation is the extent it is able to rein into expenditures of the budget - see Alesina and Perotti (1997) or Hagen, Hallett and Strauch (2001). In this part we, thus, analyse in more details the expenditure structure of the NMS budgets. However, the data on expenditures are least satisfactory on the expenditure side of a budget. Data on many expenditure items (social security, defence, etc.) are not readily available, so we use the data based on ESA95 methodology collected by the European Commission. Brief description of ESA95 expenditure categories is thus needed.

In what follows, we use basic ESA95 expenditure categories, which are compensation of employees; collective consumption; social transfers in kind; social transfers other than in kind; interest; subsidies; and gross fixed capital formation. ${ }^{7}$

Compensation of employees is self-explanatory category. Collective consumption is defined as expenditure on those services, which are intended simultaneously for all members of the society, i.e. in more economic terms, it is the expenditure on provision of public goods. Social transfers in kind cover those expenditures through which government purchases and provides certain goods for some members of the society, while social transfers other than in kind cover those expenditures through which government grants certain aid to its members in cash. Again, in more economic terms, both types of social transfers can be regarded as redistribution expenditures. Interest are expenditures government pays to cover the costs of public borrowing and subsidies are government unrequited payments, mainly to producers.

Note that collective consumption, both categories of social transfers, subsidies, interest as well as minor "other" category sum up to total current expenditure category we also use. Last ESA95 category is gross fixed capital formation or in more economic terms government investment, which with total current expenditure adds up to almost $100 \%$ of the budget expenditure with rest formed by "other" items.

Looking at the shares of GDP of various expenditure items in NMSs and EUR-15 first reveals certain differences between the groups of countries and also offers few hints about origins of current budgetary problems of EDP countries.

\footnotetext{
${ }^{7}$ While the data from the GFS would be more appropriate here, they are published only randomly and could not be used for our purposes.
} 
Chart 8a reveals fast growth of public employees' compensation in EDP countries which rose by more than two percent of GDP over last years. On the other hand, non EDP countries managed to decrease share of this expenditure category by $1 \%$ of GDP over the same period. Chart also reveals that current consolidation efforts of EDP countries will most probably be on the expense of public employees in those countries.

Similar story can be found when looking at chart $8 \mathrm{~b}$ denoting share of public goods expenditure in GDP. Although relatively higher in EDP and non EDP countries as compared to EUR-15, non EDP countries managed to decrease public goods expenditure by more than $2 \%$ of GDP over the same period when this expenditure budget category rose in EDP countries.

There seems to be no considerable difference between EDP and non EDP countries in their expenditure on social transfers outlined in chart $8 \mathrm{c}$, nevertheless, what has to be noted is a low share of GDP devoted to this budget category as compared to EUR-15 countries. Also of importance might be the fact that social transfers of both kinds alone form approximately the same share of GDP in NMSs as previously described two expenditure categories.

Expenditures on subsidies denoted by chart $8 \mathrm{~d}$ present relatively small part of GDP in EDP and non EDP countries, as well as in EUR-15 countries. Notable is also continuous decrease of this expenditure category in EDP countries which suggests that at least part of Chart 8a: Compensation of employees, \% of GDP

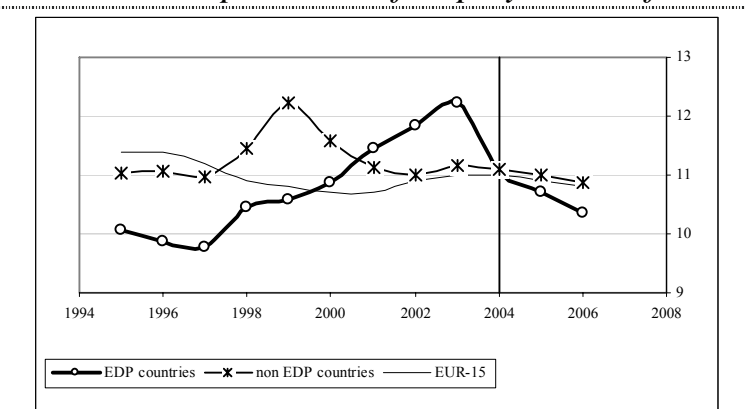

Chart 8b: Collective consumption, \% of GDP

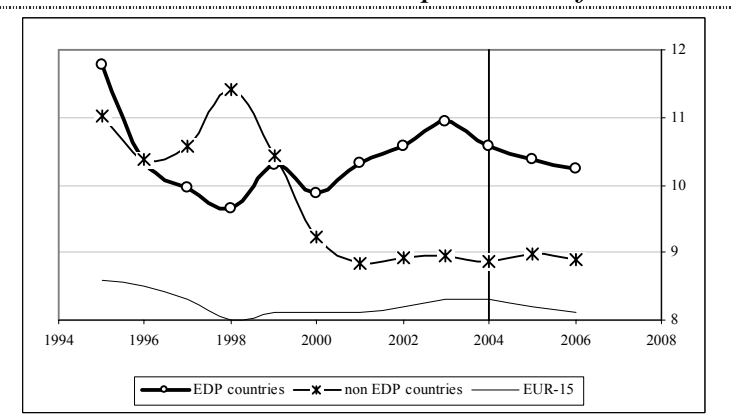

Chart 8c: Social transfers (both kinds), \% of GDP

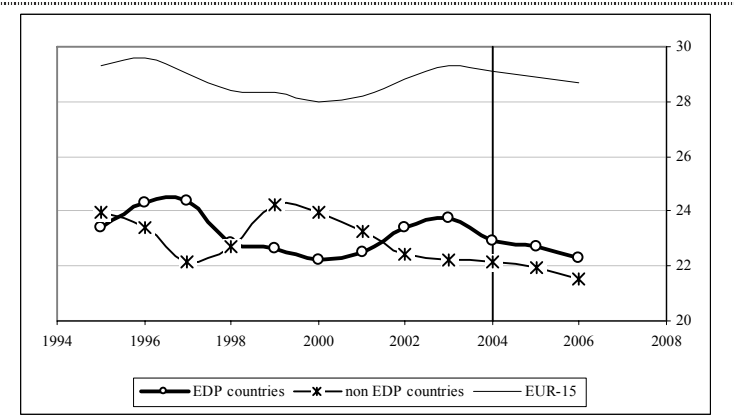

Chart 8d: Subsidies, \% of GDP

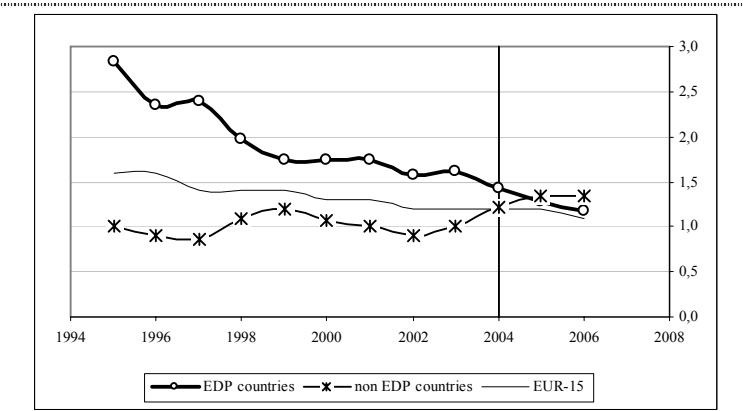

Source: European Commission (2004b) budget deficit problems of those countries in past might have been due to high tendency to financially assist companies. From the different perspective, decrease of expenditure on subsidies might reflect slow phasing out of transformation related costs. 
Last chart $8 \mathrm{e}$ denotes expenditure on public investment projects. It is not surprising to find out higher share of investment expenditure in NMSs in general and in EDP countries in particular, since many NMSs face substantial demand for infrastructure reconstruction and development after communist era which has left it in critical conditions.

Stagnation of public investment expenditure in EDP countries and increase in

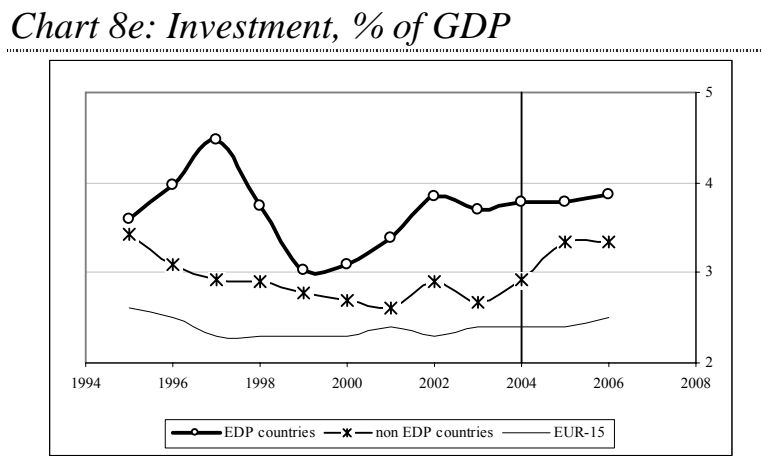

Source: European Commission (2004b) non EDP countries on the other hand might reflect the fact, that non EDP countries in general are less economically developed ones (except Slovenia and Cyprus) when measured by GDP per capita terms.

\section{POLITICAL ECONOMY OF BUDGET DEFICITS}

In this section, we analyse political aspects of public budgets in the NMS. First, we look for the existence of political business cycle. For that purpose, we calculated average real growth rate of expenditure items separately for election and non-election years for the period between 1999 and 2004. ${ }^{8}$ Our hypothesis was that government expenditure would tend to grow faster in election than in non-election years. However, the data show no significant difference in real growth rates of different expenditure items between election and nonelection years, with our expected logic being reversed in some cases. ${ }^{9}$

Second, we estimate the governments' freedom to manipulate fiscal policy according to their political preferences. For this purpose, division of budget into those expenditures which can be readily influenced and those outside the direct influence is made. Following the example of Hagen and Harden (1992) ${ }^{10}$, we defined so called open-ended expenditure as the sum of public employees' remuneration, social transfers other than social transfers in kind (social transfers in cash) and interest. Interest payments are clearly beyond direct influence of government barring a government default. Government employees' remuneration are beyond the governments' discretion due to bargaining power of the public administration employees. Last, social transfers are extremely difficult to cut as it requires legal changes that tend to be lengthy and associated with considerable political costs.

Note that open-endness is more political than economic category. However, the higher the open ended expenditures share either to GDP or to total government expenditure, the more difficult expenditure cuts become. High share of open-ended expenditure also indicates higher probability of expenditure over-runs in case of adverse economic developments.

\footnotetext{
${ }^{8}$ In order to capture the fact that policy-makers would probably tend to please their voters with higher public expenditure before the elections, we defined election year as the year immediately preceding the elections if elections took place in the first half of the relevant year and as the year when elections actually took place when they were held in the second half of the year.

${ }_{9}$ The detail results are available upon request, but we do not include them in the paper.

${ }^{10}$ Hagen and Harden (1992) found statistically significant and positive correlation between share of open-ended expenditure and level of public debt for EUR-15.
} 
Chart 9 presents results of our analysis for EDP, non EDP and EUR-15 countries. Looking at the chart $9 \mathrm{a}$, there seems to be no difference between EDP and non EDP countries in the open ended expenditure share in total government budget. Both groups of countries spend around $60 \%$ of their budgets on pre-determined purposes. Referring to the composition of the budget, this is given by the fact that higher employees' remuneration in non EDP countries is offset by lower interest payments in those countries. However, chart $9 \mathrm{~b}$ shows that share of open-ended expenditure in GDP is markedly higher in the EDP countries as compared to the non EDP countries. Moreover, the trend has been resolutely upwards since 1998, while the share has fallen in the non EDP countries (to still massive $24 \%$ of GDP). This suggests

Chart 9a: Open ended expenditure, \% of budget

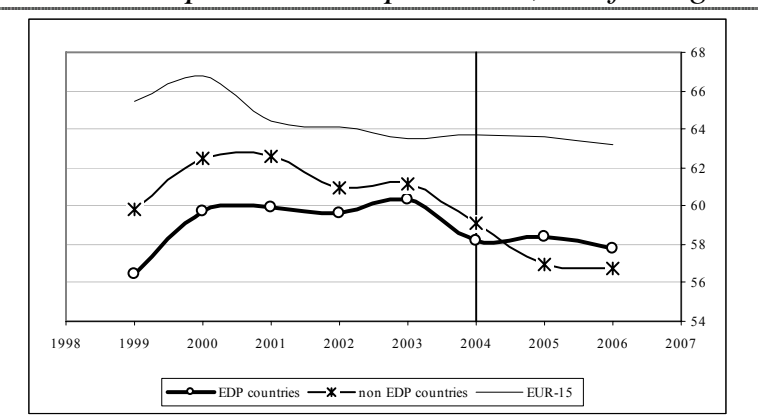

Chart 9b: Open ended expenditure, \% of GDP

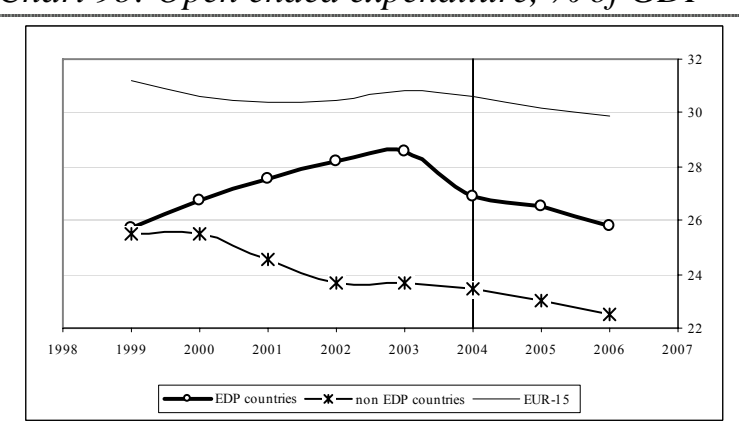

Source: European Commission (2004b); Authors' calculations that cutting government expenditure in the EDP countries requires more effort than in the non EDP countries.

It is rational, thus, to estimate which factors have been influencing budget deficits in NMSs. For that purpose, we run a simple regression whereby we estimated budget deficits using economic and political variables.

Among economic determinants, we included variable measuring output gap in NMSs, GAP, building on the idea that budget balance tends to deteriorate with economic growth below its potential. Based on the notion that restricted monetary conditions through fixed exchange rate or pegged currency discipline policy-makers who then refrain from fiscal expansion in order not to disturb external macroeconomic equilibrium ${ }^{11}$, we include variable measuring external imbalance, EXT. This variable is multiple of current account deficit in percent of GDP with dummy variable that takes on value of one if given NMS in given year had its exchange rate fixed or pegged to another currency.

For political economy factors, we built on the literature investigating effect of different institutional setup and agents involved in budget preparation, budget approval and budget implementation stages on fiscal discipline. ${ }^{12}$ In this respect, three different factors are usually mentioned. First, power of finance minister (MF) during preparatory budget stage and during negotiations about budget in cabinet is usually investigated. Second factor is influence

${ }^{11}$ Sun (2004) showed in model based framework, that disciplining effect of fixed exchange rate on fiscal policy is dependent on discount factors of policy-makers and for certain values does not necessarily hold. Canzoneri, Cumby and Diba (2001) argue that restricted monetary policy is not compatible with irresponsible fiscal policy. For empirical investigation with mixed results but with lower budget deficits associated with restricted monetary policy, see Fatas and Rose (2001).

${ }^{12}$ Hagen and Harden (1992) found impact of finance minister powers and parliamentary influence on fiscal discipline in EUR-15. For recent study of the same issue in EUR-15, see Hallerberg, Strauch and Hagen (2001 and 2004). For investigation of this topic in NMSs, see Gleich (2002 and 2003) and Ylaoutainen (2004). 
of parliament on final budget and third factor is power of MF during budget implementation stage and his supervising authority. We collected indexes describing power of MF during preparatory and implementation budget stages as well as index describing influence of parliament. All indexes are constructed such that higher value is presumed to imply higher fiscal discipline. Because indexes from different studies are applicable to years 2001, 2002 and 2003 (Gleich (2002), Ylaoutinen (2004) and Gregor (2004)) which is suitable for our purposes, we avoided difficulty of their direct comparability by using ranks, rather than directly using values of different indexes.

Our political economy variables are thus power of MF during budget preparatory stage and during negotiations in cabinet, FMC, influence of parliament on final shape of budget, PAR, power of MF during budget implementation stage, FMI, and dummy which takes on value of unity in elections year as defined above. Because our data range from 2001 through 2003 for each NMS, we arranged them into a panel using random effect model for estimation of parameters. Results are given in the table 1.

\begin{tabular}{lcccc}
\hline \multicolumn{4}{c}{ Table 1: Determining factors of budget balances in NMSs, 2001-2003 } \\
\hline GAP & $-0,24$ & $-0,11$ & $-0,05$ & $-0,24$ \\
& $(0,48)$ & $(0,55)$ & $(0,48)$ & $(0,43)^{* * *}$ \\
EXT & $-0,45^{* * *}$ & $-0,41^{* * *}$ & $-0,30^{* *}$ & $-0,38^{* * *}$ \\
& $(0,14)^{* * *}$ & $(0,16)$ & $(0,14)$ & $(0,13)^{* * *}$ \\
FMC & $0,60^{* *}$ & & & $0,57^{* *}$ \\
& $(0,22)$ & & & $(0,20)$ \\
PAR & & 0,08 & & 0,08 \\
& & $(0,26)$ & & $(0,21)^{* * *}$ \\
FMI & & & $0,60^{* *}$ & $0,52^{* * *}$ \\
& & & $(0,23)$ & $(0,20)$ \\
EL & 0,97 & 0,15 & 0,24 & 0,72 \\
& $(1,22)$ & $(1,44)$ & $(1,20)$ & $(1,12)$ \\
C & $-8,23^{* * *}$ & $-5,48^{* * *}$ & $-7,09^{* * *}$ & $-10,18^{* * *}$ \\
& $(1,52)$ & $(1,55)$ & $(1,24)$ & $(1,72)$ \\
$\mathrm{R}^{2}$ & 0,42 & 0,25 & 0,41 & 0,56 \\
\hline
\end{tabular}

Note: Estimates for NMS (excluding Malta and Cyprus) for 2001 through 2003. Dependent variable general government deficit (surplus with “+” sign). GAP is deference between actual and potential output. EXT is current account deficit to GDP ratio times dummy which takes on value of unity if country has restricted monetary policy (fixed exchange rate). FMC is index of MF power during cabinet negotiations (higher values imply stronger MF) and FMI is index of MF power during implementation of the budget. PAR is index capturing parliamentary influence. Sources of indexes for different years are Gleich (2002), Ylaoutinen (2004) and Gregor (2004) and rank classification has been used to avoid problem of direct incomparability. EL is dummy taking on value of unity in elections years (definition used in the text). Economic data from AMECO database. Random effect panel data estimation (unambiguously implied by Hausman statistics on all levels of significance). Standard errors in parentheses. *** significant on $1 \%$, ** significant on $5 \%$ and $*$ significant on $10 \%$.

Estimated coefficient for output gap is insignificant in all specifications and even has a wrong sign as budget surplus should be increasing function of output gap. This finding in fact suggests that governments in NMSs are not able to stabilize economic cycle in their countries.

Opposite holds for the estimated coefficient capturing effect of external factors with conjunction to fixed or restricted exchange rate. Coefficients are negative and significant in all specifications, suggesting that worsening current account balance has non-negligible disciplining effect of fiscal policy.

As for estimated coefficients for political economy variables, power of MF seems important to fiscal discipline as budget position improves with rising power of MF. Also little change of estimated coefficients and increase of explanatory power of the model after the 
inclusion of both variables measuring MF powers suggest that MF power during cabinet negotiations and MF power during budget implementation are complements to fiscal discipline, rather than substitutes.

On the other hand, our other two political economy variables capturing parliamentary influence and presence of elections are insignificant in all specifications. This finding shows that parliaments in NMSs do not have significant influence on final budget and therefore on its deficit and, besides not being able to use fiscal policy for economic stabilization, policymakers in NMSs are not able to use fiscal policy for electoral purposes or do so in a way that does not show in the budget deficit data.

To sum up this section, EDP countries are those with significantly higher government involvement in the economy as measured by the share of revenues and expenditures to GDP. While internal composition of revenue side of the budget does not differ between EDP and non EDP countries, NMSs rely more heavily on indirect taxation when compared to EUR-15. Shifting attention to expenditure side of the budget revealed higher share of budgets in non EDP countries devoted to employees' remuneration, social transfers in kind and lower share spent on interest payments.

The EDP countries have aggravated their budget woes by allowing a faster growth of employees' remuneration and both types of social transfers in the past. This higher growth rates have reversed lately, reflecting effort of the EDP countries to cut budget deficits. However, authorities in the EDP countries had waited until the very last moment before any action in this respect and then applying sudden stop strategy. The non EDP countries could afford a more gradual reduction in expenditures growth rates. Data also reveal that while major part of consolidation effort in EDP countries falls on employees' remunerations and social transfers of both kinds, the EDP countries have also reined in their investment expenditures, limiting long-term growth prospects in order to comply with European fiscal rules.

Although no significant proof of electoral cycle can be found in the data, high share of open-ended expenditure to GDP in EDP countries suggests that any consolidation effort in those countries would be more demanding and associated with higher political costs. Also, high share of open-ended expenditure to GDP in the EDP countries renders budgets in those countries more exposed to unexpected events and would thus be associated with rapid budget deterioration if an unexpected negative shock occurs. ${ }^{13}$

Therefore, current problems of EDP countries with SGP seem to be given by the mix of their larger governments' involvement in the economy, by higher rigidity of their budgets, and by the fact that policy-makers in those countries has recently allowed for escalation of politically sensitive expenditure items.

13 Another stylized fact about public sectors in NMSs is low effectiveness of automatic stabilizers, confirmed for example by findings of Orban and Szapary (2004). Based on their estimates (excluding Cyprus and Malta for which estimates are not available), average budget elasticity with respect to real GDP growth is 0,433 for EDP countries and 0,380 for non EDP countries with difference significant on $12 \%$ confidence level and both averages lower than EUR-15 average of 0,500 . 


\section{GROWTH ACCOUNTING - WHERE HAVE THE CONSOLIDATIONS COME FROM?}

In this section we apply growth accounting technique proposed by Hagen, Hallett and Strauch (2001) and used by Hallett, Lewis and Hagen (2004) in order to disentangle the effect of growth of economy and effect of fiscal policy effort on the changes in government budget deficit in NMSs in the period 2001 through 2004. It has to be noted that this technique does rely neither on estimates of elasticity of budget with respect to GDP growth nor on estimates of cyclically adjusted budget balance. That is, in what follows, we do not attempt to estimate cyclically adjusted budget balance in NMSs. ${ }^{14}$

The Hagen, Hallett and Strauch method estimates what proportion of the change in the budget balance is caused by growth of the economy; what proportion is caused by a change in monetary policy conditions; what proportion is due to a change in the level of public debt; and, finally, what proportion can be described as net fiscal effort which is supposed to capture restrictiveness or expansiveness of fiscal policy in given country and given year. If we combine the net fiscal effort with information about cyclical position of economy from AMECO database, it is possible to estimate whether given fiscal policy is pro-cyclical or anticyclical.

The growth accounting method is simple; we define government budget deficit in percentage of GDP as

$$
d=(G-T) / Y=g-t
$$

where $G$ denotes total government expenditure, $T$ total government (tax) revenues and $Y$ national output (GDP). Thus $g$ and $t$ is government expenditure and revenue expressed in percentage of GDP terms. From (1) it follows that change in government deficit to GDP ratio is given by

$$
\Delta d=\frac{\Delta G-\Delta T}{Y}-\frac{(G-T) \Delta Y}{Y^{2}}=\frac{\Delta G-\Delta T}{Y}-\dot{\gamma}(g-t)
$$

where $\dot{\gamma}$ denotes rate of growth of GDP.

\section{Growth effects}

As we want to estimate expansion (or restrictive) effects of fiscal policy we need to define neutral fiscal policy. Following Hagen, Hallett and Strauch we use three different definitions. The first definition of neutral fiscal policy is the one in which the average tax rate, $t$, defined as $t=T / Y$ as well as the level of public expenditure, $G$, is held constant. This implies that $\Delta G=0$ and $\Delta T=t \Delta Y$ which after substitution into (2) realizing that expenditures equal taxes plus deficit, $g=t+d$, gives

$$
\Delta d=-\dot{\gamma} \cdot(t+d)
$$

The second definition of neutral fiscal policy is based on idea that government allows its expenditures to grow in line with increase in revenues but no more. This logic implies that

${ }^{14}$ Although all NMSs present estimates of cyclically adjusted budget balance in their CoPrs and many of them in PEPs, those estimates are inappropriate for our purpose for two reasons. First, they are not based on unified methodology. Second, they in many instances do not cover whole pre-accession period of 2001 through 2004. Growth accounting allows us to overcome those two complications. 
$\Delta T=\Delta G$ which after substitution into (2) gives

$$
\Delta d=-\dot{\gamma} \cdot d
$$

The final definition of neutral fiscal policy allows government expenditure to grow by the rate of growth of potential output but no faster and requires average tax rate to remain constant. In this case, $\Delta G=g \bar{\gamma}$ where $\bar{\gamma}$ denotes growth of potential output and combined with $\Delta T=t \Delta Y$ after substitution into (2) gives

$$
\Delta d=\frac{g \bar{\gamma}-t \Delta Y}{Y}-\dot{\gamma}(g-t)=g \cdot(\bar{\gamma}-\dot{\gamma})
$$

Equations (3) and (4) imply that government budget deficit should not change if there is no economic growth $(\dot{\gamma}=0)$ in order to keep neutral fiscal policy. If there is positive economic growth, $(\dot{\gamma}>0)$, government budget deficit should be reduced be rate implied by the equations.

Equation (5) implies that government budget deficit should not change if the actual rate of growth equals rate of growth of potential output. If growth of potential output exceeds that of actual output, government budget deficit should increase in order for fiscal policy to be neutral.

An alternative interpretation of equations (3) through (5) is that whatever the observed reduction of government budget deficit, part of this reduction came from growth of the economy, irrespective of fiscal policy efforts.

Note also, that the three definitions are not equally restrictive with respect to fiscal policy. First definition, which requires the government expenditure to remain constant in nominal terms, is the most restrictive one. On the other hand, the second definition that allows government to increase its expenditure by the amount of extra revenues, is the least restrictive one because neutral fiscal policy can be associated with increasing government expenditure. Third definition can be regarded as a compromise and we will refer to it in the following text.

\section{Monetary effects}

Growth accounting also allows for detection of the effect of change of monetary conditions and of the effect of change in level of public debt. Let $x=r \cdot(B / Y)$ be the ratio of interest payments to GDP, where $r$ is the average interest rate applicable to government debt, $B$ is the volume of government debt and therefore $b$ is government debt to GDP ratio. Assuming $x$ is small, its change can be approximated by

$$
\Delta x=(\Delta r) b+r(\Delta b)
$$

where $(\Delta r) b$ reflects a change in interest payments on government debt generated by a change in interest rate and $r(\Delta b)$ reflects a change in interest payments due to the reduction of the stock of debt.

Combining effects on government budget deficit coming from economic growth given by equation (5) with change in interest payments given by equation (6) approximates change in government budget deficit which is due solely to change in economic conditions. Alternatively, taking observed reduction of government budget deficit and subtracting the effect of change in economic conditions reveals that part of reduction coming from net fiscal 
effort, which subsequently allows for judgment about restrictiveness or expansiveness of fiscal policy.

Result of application of growth accounting technique on fiscal policy in NMSs in years 2001-2004 are given in tables 2a-2d. When discussing results, we concentrate on values exceeding unity since lower values are too low to interpret using the growth accounting method. The exception is the stabilization function of fiscal policy where we are concerned with sign of net fiscal effort and of output gap. Also, we primarily use the third definition of neutrality, denoted as "Due to economic growth III".

Note that net fiscal effort with positive sign implies expansionary fiscal policy. Also, positive output gap denotes economy above its potential. Therefore, positive sign for net fiscal effort combined with positive sign for output gap mean that fiscal policy is pro-cyclical. Exactly the same logic implies for case when net fiscal effort and output gap are negative, denoting a situation of restrictive fiscal policy and economy below its potential. Thus, in order for fiscal policy to be anti-cyclical, net fiscal effort and output gap should have inverse signs.

\begin{tabular}{|c|c|c|c|c|c|c|c|c|c|c|}
\hline \multicolumn{11}{|c|}{ Table 2a: Growth Accounting, \% of GDP, data for 2001} \\
\hline & $\mathrm{CY}$ & $\mathrm{CZ}^{*}$ & $\mathrm{EE}$ & LV & $\mathrm{LT}$ & $\mathrm{HU}^{*}$ & $\mathrm{MT}^{*}$ & $\mathrm{PL}^{*}$ & SI & $\mathrm{SK}^{*}$ \\
\hline Observed reduction & $-0,10$ & 2,30 & $-0,80$ & $-0,70$ & $-0,50$ & 1,40 & 0,20 & 3,10 & $-0,70$ & $-6,30$ \\
\hline Due to economic growth III & $-0,12$ & $-0,45$ & $-0,37$ & $-0,58$ & $-0,70$ & 0,10 & 2,32 & 1,05 & 0,53 & $-0,67$ \\
\hline Impact of monetary policy & $-0,06$ & 0,18 & 0,00 & $-0,07$ & $-0,18$ & $-0,43$ & $-0,37$ & 0,99 & $-0,22$ & $-0,39$ \\
\hline Impact of change in debt & 0,16 & 0,45 & $-0,02$ & 0,16 & $-0,06$ & $-0,19$ & 0,37 & $-0,01$ & 0,07 & $-0,10$ \\
\hline Due to economic growth I & $-1,56$ & $-1,23$ & $-2,32$ & $-3,09$ & $-2,29$ & $-1,88$ & 0,98 & $-0,45$ & $-1,24$ & $-2,02$ \\
\hline Due to economic growth II & $-0,10$ & $-0,15$ & 0,02 & $-0,17$ & $-0,13$ & $-0,17$ & 0,14 & $-0,04$ & $-0,08$ & $-0,23$ \\
\hline Net fiscal policy effort & $-0,08$ & 2,12 & $-0,41$ & $-0,21$ & 0,45 & 1,92 & $-2,12$ & 1,07 & $-1,07$ & $-5,14$ \\
\hline Output Gap & 1,80 & $-0,90$ & 0,20 & 0,10 & $-2,80$ & 0,40 & $-0,60$ & $-2,20$ & 0,00 & $-0,90$ \\
\hline \multicolumn{11}{|c|}{$\begin{array}{l}\text { Note: Negative observed reduction of government budget deficit denotes improvement of budget deficit. Change due to economic growth } \\
\text { III is given by equation (5) and impact of monetary policy and impact of change in debt by equation (6). Change due to economic growth I } \\
\text { and II are illustrative only. Net fiscal effort based on third definition of neutral fiscal policy and given as observed reduction less sum of } \\
\text { effect of growth, monetary policy and change in debt. Positive net fiscal effort denotes expansionary fiscal policy. Output gap defined as } \\
\text { actual less potential output with negative values denoting recessions. Values of equal signs in last two rows denote pro-cyclical policy. } \\
\text { * denotes countries that did not comply with SGP } 3 \% \text { of GDP limit for budget deficit in given year. } \\
\text { Source: Authors' calculations based on European Commission (2004b) and AMECO data }\end{array}$} \\
\hline
\end{tabular}

Table reveals the fact that in year 2001, fiscal policy in Czech Republic, Hungary and Poland was strongly expansionary (net fiscal effort was higher than 1, indicating strong relaxation of fiscal policy). In case of Czech Republic and Poland the relaxation of fiscal policy was anti-cyclical and in case of Hungary the relaxation of fiscal policy was even procyclical as Hungary had positive output gap (was above its potential). On the other hand, fiscal policy in Malta, Slovenia and Slovakia was strongly restrictive despite negative output gap in Malta and Slovakia and neutral economic position in Slovenia.

Should we accept also lower values of net fiscal effort and combine them with output gap, we find that three out of ten NMSs (Hungary, Malta and Slovakia) experienced procyclical fiscal policy (Hungary expansionary and Malta and Slovakia restrictive).

Note also that results for different definitions of neutral fiscal policy correspond to their different restrictiveness. First and most restrictive definition in every case always require larger reduction of government budget deficit than second and least restrictive definition. 


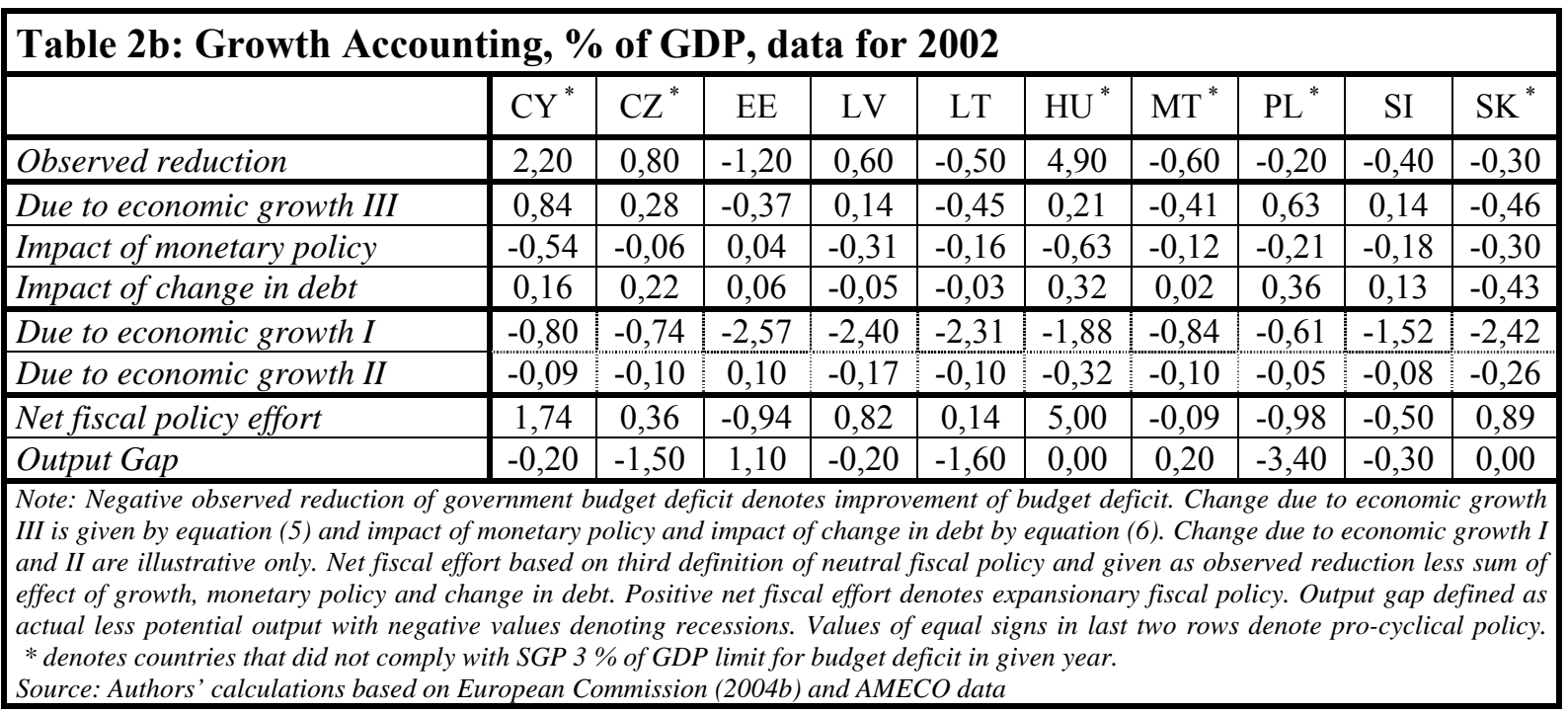

Results imply that in year 2002, fiscal policy was expansionary in Cyprus and (massively) in Hungary with anti-cyclical nature in case of Cyprus and non-neutral position in case of Hungary. On the other hand, there are no countries that displayed restrictive fiscal policy in 2002, even though Estonia and Poland were very close to the threshold. In the year 2002 governments were slightly more successful in stabilising their economies: only two out of the ten NMS ran a pro-cyclical policy (Poland and Slovenia) although Hungary and Slovakia seemed to be a bit too expansionary, given their neutral business cycle position.

Table $2 \mathrm{c}$ shows results of the growth accounting methodology for last pre-accession year, 2003. Given their high deficits and the imminent SGP application, one would expect strong consolidation efforts or at least strongly restrictive fiscal policy in most NMS countries. However, only Estonia, Hungary and Slovakia showed a restrictive fiscal policy effort, while Czech Republic, Lithuania and Malta merrily run an expansionary policy. ${ }^{15}$ Lithuania was even running pro-cyclical fiscal policy, with a positive output gap. Hungary reversed its 2002 policy and tightened fiscal policy significantly, although the economy was below potential. Four out of ten countries (Estonia, Lithuania, Hungary and Slovenia) run procyclical policies in 2003 (restrictive in Estonia, Hungary and Slovenia and expansive in Lithuania).

${ }^{15}$ Very high increase of budget deficit in Czech Republic is given partly by change in methodological treatment in government guarantees which show as one-off measure in Czech Republic statistics. However, without one-off measures, observed reduction in Czech Republic would be equal to -1,20 implying net fiscal effort of $-0,99$. 


\begin{tabular}{|c|c|c|c|c|c|c|c|c|c|c|}
\hline \multicolumn{11}{|c|}{ Table 2c: Growth Accounting, \% of GDP, data for 2003} \\
\hline & $\mathrm{CY}^{*}$ & $\mathrm{CZ}^{*}$ & EE & LV & $\mathrm{LT}$ & $\mathrm{HU}^{*}$ & $\mathrm{MT}^{*}$ & $\mathrm{PL}^{*}$ & SI & $\mathrm{SK}^{*}$ \\
\hline Observed reduction & 1,80 & 5,90 & $-1,60$ & $-1,20$ & 0,40 & $-3,00$ & 3,80 & 0,30 & $-0,40$ & $-2,00$ \\
\hline Due to economic growth III & 0,60 & $-0,16$ & 0,50 & $-0,29$ & $-1,19$ & 0,35 & 0,59 & $-0,52$ & 0,53 & $-0,04$ \\
\hline Impact of monetary policy & 0,28 & $-0,49$ & $-0,08$ & 0,06 & $-0,06$ & $-0,35$ & $-0,07$ & $-0,14$ & $-0,44$ & $-0,68$ \\
\hline Impact of change in debt & 0,20 & 0,44 & 0,00 & 0,02 & $-0,06$ & 0,15 & 0,51 & 0,34 & $-0,01$ & $-0,04$ \\
\hline Due to economic growth I & $-0,88$ & $-1,76$ & $-1,75$ & $-2,79$ & $-3,28$ & $-1,53$ & $-0,10$ & $-1,66$ & $-1,16$ & $-1,64$ \\
\hline Due to economic growth II & $-0,13$ & $-0,39$ & 0,16 & $-0,11$ & $-0,18$ & $-0,19$ & $-0,02$ & $-0,15$ & $-0,05$ & $-0,15$ \\
\hline Net fiscal policy effort & 0,72 & 6,11 & $-2,02$ & $-0,99$ & 1,72 & $-3,15$ & 2,77 & 0,62 & $-0,48$ & $-1,23$ \\
\hline Output Gap & $-1,40$ & $-1,10$ & $-0,20$ & 0,40 & 1,70 & $-0,70$ & $-1,00$ & $-2,50$ & $-1,40$ & 0,10 \\
\hline \multicolumn{11}{|c|}{$\begin{array}{l}\text { Note: Negative observed reduction of government budget deficit denotes improvement of budget deficit. Change due to economic growth } \\
\text { III is given by equation (5) and impact of monetary policy and impact of change in debt by equation (6). Change due to economic growth I } \\
\text { and II are illustrative only. Net fiscal effort based on third definition of neutral fiscal policy and given as observed reduction less sum of } \\
\text { effect of growth, monetary policy and change in debt. Positive net fiscal effort denotes expansionary fiscal policy. Output gap defined as } \\
\text { actual less potential output with negative values denoting recessions. Values of equal signs in last two rows denote pro-cyclical policy. } \\
\text { * denotes countries that did not comply with SGP } 3 \% \text { of GDP limit for budget deficit in given year. } \\
\text { Source: Authors' calculations based on European Commission (2004b) and AMECO data }\end{array}$} \\
\hline
\end{tabular}

Table $2 \mathrm{~d}$ shows data for the year of EU accession for the ten NMSs. Surely, they would show net fiscal effort to assure old members, EUR-15, that the enlarged EU will be fiscally manageable.

However, table $2 \mathrm{~d}$ does not suggest any considerable consolidation effort. ${ }^{16}$ Only Malta displays net fiscal effort that confirms the hypothesis of strong consolidation. Cyprus observed reduction in the budget deficit, but benefited from economic growth and improvement in monetary policy and thus displays rather neutral fiscal policy. Czech Republic, although experiencing reduction in budget deficit, owes this improvement to economic growth and change in monetary policy conditions with net fiscal effort showing neutral fiscal policy. Observed reduction of budget deficit in Hungary is on the other hand given by fiscal effort but is not considerable enough to classify for restrictive fiscal policy. Observed budget stance in Poland in fact deteriorated in 2004 and can be classified as strongly expansionary. Slovakia can be classified as neutral with respect to both observed and net fiscal policy stance.

Table 2d: Growth Accounting, \% of GDP, data for 2004

\begin{tabular}{|l|c|c|c|c|c|c|c|c|c|c|}
\hline & $\mathrm{CY}^{*}$ & $\mathrm{CZ}^{*}$ & $\mathrm{EE}$ & $\mathrm{LV}$ & $\mathrm{LT}$ & $\mathrm{HU}^{*}$ & $\mathrm{MT}^{*}$ & $\mathrm{PL}^{*}$ & $\mathrm{SI}^{*}$ & $\mathrm{SK}^{*}$ \\
\hline Observed reduction & $-1,20$ & $-7,80$ & 2,50 & 0,50 & 0,70 & $-0,70$ & $-4,50$ & 1,70 & 0,30 & 0,20 \\
\hline Due to economic growth III & $-0,14$ & $-0,23$ & 0,23 & $-0,11$ & $-0,14$ & $-0,05$ & 0,42 & $-1,13$ & $-0,24$ & $-0,23$ \\
\hline Impact of monetary policy & $-0,36$ & $-0,53$ & 0,01 & 0,01 & $-0,04$ & 0,06 & $-0,43$ & $-0,14$ & $-0,09$ & $-0,22$ \\
\hline Impact of change in debt & 0,09 & 0,00 & $-0,03$ & 0,01 & $-0,02$ & 0,05 & 0,11 & 0,17 & 0,11 & 0,09 \\
\hline Due to economic growth I & $-1,53$ & $-1,85$ & $-2,43$ & $-2,72$ & $-2,47$ & $-1,91$ & $-0,47$ & $-2,64$ & $-1,83$ & $-1,89$ \\
\hline Due to economic growth II & $-0,18$ & $-0,18$ & 0,03 & $-0,15$ & $-0,18$ & $-0,21$ & $-0,05$ & $-0,32$ & $-0,09$ & $-0,19$ \\
\hline Net fiscal policy effort & $-0,79$ & $-7,04$ & 2,28 & 0,58 & 0,90 & $-0,76$ & $-4,60$ & 2,80 & 0,52 & 0,56 \\
\hline $\begin{array}{l}\text { Output Gap } \\
\text { Note: Negative observed reduction of government budget deficit denotes improvement of budget deficit. Change due to economic growth }\end{array}$ \\
$\begin{array}{l}\text { III is given by equation (5) and impact of monetary policy and impact of change in debt by equation (6). Change due to economic growth I } \\
\text { and II are illustrative only. Net fiscal effort based on third definition of neutral fiscal policy and given as observed reduction less sum of } \\
\text { effect of growth, monetary policy and change in debt. Positive net fiscal effort denotes expansionary fiscal policy. Output gap defined as } \\
\text { actual less potential output with negative values denoting recessions. Values of equal signs in last two rows denote pro-cyclical policy. } \\
\text { * denotes countries that did not comply with SGP 3 \% of GDP limit for budget deficit in given year. } \\
\text { Source: Authors' calculations based on European Commission (2004b) and AMECO data }\end{array}$ \\
\hline
\end{tabular}

${ }^{16}$ Again, without counting for one-off measures in case of Czech Republic, observed reduction would be $-0,80$ and net fiscal effort $-0,04$. 
While in 2003 most NMSs run counter-cyclical fiscal policy, the year 2004 was almost opposite: seven out of the ten run pro-cyclical fiscal policy in 2004. Only Estonia, Poland and Slovenia stabilised their respective economies in 2004.

The weak fiscal performance in 2004 is all the more puzzling, given the exceptionally positive external conditions. For five EDP countries (Cyprus, Czech Republic, Hungary, Poland and Slovakia) economic growth contributed to fiscal consolidations. The same holds for monetary policy impact (that benefited Cyprus, Czech Republic, Malta, Poland and Slovakia and only marginally harmed Hungary). Thus, the EDP countries mostly wasted beneficial economic conditions in 2004.

\begin{tabular}{|c|c|c|c|c|c|c|c|c|c|c|}
\hline \multicolumn{11}{|c|}{ Table 2e: Net Fiscal Efforts, \% of GDP, 2001-2004 } \\
\hline & $\mathrm{CY}^{*}$ & $\mathrm{CZ}^{*}$ & $\mathrm{EE}$ & LV & LT & $\mathrm{HU}^{*}$ & $\mathrm{MT}^{*}$ & $\mathrm{PL}^{*}$ & $\mathrm{SI}^{*}$ & $\mathrm{SK}^{*}$ \\
\hline 2001 & $-0,08$ & 2,12 & $-0,41$ & $-0,21$ & 0,45 & 1,92 & $-2,12$ & 1,07 & $-1,07$ & $-5,14$ \\
\hline 2002 & 1,74 & 0,36 & $-0,94$ & 0,82 & 0,14 & 5,00 & $-0,09$ & $-0,98$ & $-0,50$ & 0,89 \\
\hline 2003 & 0,72 & 6,11 & $-2,02$ & $-0,99$ & 1,72 & $-3,15$ & 2,77 & 0,62 & $-0,48$ & $-1,23$ \\
\hline 2004 & $-0,79$ & $-7,04$ & 2,28 & 0,58 & 0,90 & $-0,76$ & $-4,60$ & 2,80 & 0,52 & 0,56 \\
\hline
\end{tabular}

To summarize this section, we may conclude that NMSs have not been very successful in stabilising their economies with fiscal policy and that their stabilisation performance has worsened over time. Out of 40 occurrences, in 16 (40\%) governments have run pro-cyclical fiscal policy. Seven these events took place in 2004. Also, the fiscal efforts were more or less evenly distributed between restrictive and expansionary. In 10 cases net fiscal effort was significantly positive (expansionary) and in 8 it was significantly negative (restrictive), remaining 22 cases being too close to neutral policy - see Table $2 \mathrm{e}$.

The EDP and non EDP countries do not differ in frequency of positive and negative net fiscal efforts. However, the two groups do differ in variance of these efforts. Among the four non EDP countries, none net fiscal effort was above $2 \%$ of GDP and in 12 out of 16 instances, the net fiscal effort was not significantly different from zero. The EDP countries have run more volatile fiscal policies often switching from highly positive net fiscal effort to highly negative one. When we exclude specific data for the Czech Republic in 2003 and 2004, the largest positive fiscal effort took place in Hungary in $2002(+5 \%)$. The largest negative fiscal effort was recorded in Slovakia in 2001 and in Malta in 2004 (-5 \%).

We can thus speculate that high share of government expenditures and their higher pre-determination (see charts $9 \mathrm{a}$ and $9 \mathrm{~b}$ ) in the EDP countries make their fiscal less predictable and more prone to periodic u-turns. This argument is supported by data from 2004 showing almost no consolidation of fiscal policy in most of the EDP countries regardless

\section{STRUCTURE OF CONSOLIDATIONS}

\section{Successful and unsuccessful consolidations}

This section builds on proposition of McDermott and Wescott (1996), Alesina and Perotti (1997) and of Perotti, Strauch and Hagen (1998) as well as on proposition of current public finance literature concerned with periods of fiscal consolidations. The literature has converged on the judgment that composition of consolidations matters. In this section, we 
look at fiscal data of NMSs spanning from 1995 through 2006 and identify periods of fiscal consolidations which we investigate furthering more details.

In accordance with the literature, we define period of fiscal consolidation as a period in which government primary budget deficit to GDP ratio (budget deficit less interest on public debt) improved by more than $1 \%$ of GDP in the first year and improved in second and later years. ${ }^{17}$ Consolidation is said to last, until government primary budget deficit to GDP is being reduced.

We define period of successful consolidation as one in which government primary budget deficit to GDP ratio two years after consolidation initiation stands at $75 \%$ or better of government primary budget deficit to GDP ratio in the year when consolidation started (or changes sign) and does not deteriorate in those two years. Unsuccessful consolidations are those which do not fulfil our condition.

Now, let $X_{e}$ be the ratio of budget item to GDP in the year when a consolidation ended and $X_{s-1}$ be the ratio of budget item to GDP in the year before a consolidation started. Then the difference $\left(X_{e}-X_{s-1}\right)$ shows by how much the budget item $X$ changed relative to GDP throughout the consolidation period.

The literature shows that the more a consolidation is based on expenditure reduction and less it is based on revenue increase, the higher is the probability that a consolidation will bring lasting improvement in budget position - see Alesina and Perotti (1997).

Results for NMSs are given in the table 3. Note that positive values for government revenue budget items denote increase in the relevant revenue item to GDP ratio throughout a consolidation and negative values for government expenditure budget items denote decrease in relevant expenditure item to GDP ratio throughout a consolidation.

Looking at consolidations that took place before the EU accession, it is apparent that on average, those consolidations has been based on government expenditure reduction and were also associated with slight government revenue decrease. Expenditure budget items that show largest decrease through the consolidations are public goods as well as redistribution expenditures. On the other hand, subsidies and expenditure for public investment were not typically reduced during the consolidation periods. The fact that investment did not fall during consolidations is rather surprising and counters arguments that governments in fiscal crisis find it easiest to cut or postpone investment - see below.

${ }^{17}$ We do not use definition of fiscal consolidation of Hagen, Hallett and Strauch (2001) because it is too restrictive and thus we would be able to identify only very few periods of fiscal consolidation in our data sample. Also, we do not use cyclically adjusted budget data because those are not readily available. 


\begin{tabular}{|c|c|c|c|c|c|c|c|c|c|c|c|c|c|c|c|}
\hline & $\begin{array}{c}\text { Primary } \\
\text { deficit }\end{array}$ & Deficit & $\begin{array}{c}\text { Total } \\
\text { revenue }\end{array}$ & $\begin{array}{c}\text { Total } \\
\text { expenditure }\end{array}$ & $\begin{array}{l}\text { Current } \\
\text { revenue }\end{array}$ & $\begin{array}{c}\text { Current } \\
\text { expenditure }\end{array}$ & $\begin{array}{l}\text { Collective } \\
\text { consumption }\end{array}$ & $\begin{array}{l}\text { Employees' } \\
\text { enumeration }\end{array}$ & $\begin{array}{l}\text { Social - } \\
\text { kind }\end{array}$ & $\begin{array}{l}\text { Social - } \\
\text { nonkind }\end{array}$ & Subsidies & $\begin{array}{c}\text { Capital } \\
\text { formation }\end{array}$ & \begin{tabular}{|c|}
$\begin{array}{c}\text { Composition of } \\
\text { consolidation } \\
\mathrm{R} / \mathrm{E}\end{array}$ \\
\end{tabular} & Year & \begin{tabular}{|c|}
$\begin{array}{c}\text { Fiscal flow } \\
\text { ending the } \\
\text { consolidation }\end{array}$ \\
\end{tabular} \\
\hline CYI & $-2,6$ & $-2,1$ & 3,8 & 1,7 & 4,0 & 1,6 & $-0,1$ & $-0,3$ & 0,0 & 0,4 & 0,7 & 0,5 & $181 \% /-81 \%$ & $2000-2001$ & $\mathrm{~B}(\mathrm{E})$ \\
\hline CYII & $-4,0$ & $-4,0$ & 1,7 & $-2,2$ & 1,9 & $-2,2$ & $-1,0$ & $-2,8$ & $-0,9$ & 0,2 & $-0,6$ & 0,3 & $42 \% / 58 \%$ & 2004-2006 & na \\
\hline CZI & $-11,1$ & $-11,0$ & $-1,0$ & $-12,0$ & $-0,3$ & 0,8 & $-0,1$ & 0,2 & 0,1 & 1,0 & $-0,1$ & $-1,1$ & $-9 \% / 109 \%$ & 1996-1997 & $\mathrm{B}(\mathrm{E})$ \\
\hline CZII & $-8,4$ & $-8,3$ & $-0,4$ & $-8,7$ & $-0,8$ & $-2,6$ & $-0,9$ & $-0,2$ & $-0,8$ & $-1,0$ & $-0,4$ & 0,2 & $-5 \% / 105 \%$ & 2004-2006 & na \\
\hline $\mathrm{EE}$ & $-6,7$ & $-6,8$ & 0,1 & $-6,8$ & $-1,1$ & $-4,7$ & $-2,0$ & $-1,6$ & $-1,3$ & $-1,0$ & $-0,2$ & $-0,8$ & $1 \% / 99 \%$ & $2000-2003$ & $\mathrm{E}$ \\
\hline LV I & $-3,3$ & $-3,5$ & 1,0 & $-2,5$ & $-0,7$ & $-3,6$ & $-0,6$ & $-0,6$ & $-3,0$ & 0,0 & $-0,2$ & 0,3 & $29 \% / 71 \%$ & 1996-1997 & $E$ \\
\hline LV II & $-3,0$ & $-2,8$ & $-3,0$ & $-5,8$ & $-3,9$ & $-6,3$ & $-1,3$ & $-1,1$ & $-0,8$ & $-3,8$ & $-0,7$ & $-0,4$ & $-107 \% / 207 \%$ & $2000-2001$ & $\mathrm{R}$ \\
\hline LT & $-4,0$ & $-4,1$ & $-4,5$ & $-8,6$ & $-4,8$ & $-5,7$ & $-1,0$ & $-2,1$ & $-1,9$ & $-2,1$ & $-0,3$ & 0,2 & $-110 \% / 210 \%$ & 2000-2002 & $\mathrm{R}$ \\
\hline $\mathrm{HU}$ & $-4,0$ & $-3,7$ & $-0,1$ & $-3,9$ & $-0,9$ & $-0,3$ & $-0,4$ & $-0,4$ & 0,3 & 0,4 & $-0,5$ & $-1,9$ & $-3 \% / 103 \%$ & 2003-2004 & $\mathrm{R}$ \\
\hline MT & $-6,3$ & $-6,3$ & 6,1 & $-0,2$ & 0,7 & $-2,3$ & $-0,2$ & $:$ & $-0,4$ & $-0,5$ & $-0,8$ & $-0,3$ & $97 \% / 3 \%$ & 2004-2006 & na \\
\hline PL & $-2,5$ & $-2,5$ & $-0,4$ & $-3,0$ & $-0,8$ & $-3,1$ & $-0,5$ & $-0,8$ & $-0,4$ & $-1,0$ & $-0,1$ & 0,4 & $-16 \% / 116 \%$ & 2005-2006 & na \\
\hline \multicolumn{14}{|c|}{ Average } & \multirow{5}{*}{\multicolumn{2}{|c|}{ All }} \\
\hline All & 5,08 & 5,01 & 0,30 & $-4,73$ & $-0,61$ & $-2,58$ & $-0,74$ & $-0,97$ & $-0,83$ & $-0,67$ & $-0,29$ & $-0,24$ & $9 \% / 91 \%$ & & \\
\hline Successful & 5,25 & 5,30 & 0,85 & $-4,45$ & $-0,82$ & $-3,73$ & $-1,05$ & $-2,17$ & $-1,13$ & $-0,85$ & $-0,48$ & $-0,15$ & $8 \% / 92 \%$ & & \\
\hline Unsuccessful & 4,99 & 4,84 & $-0,01$ & $-4,89$ & $-0,49$ & $-1,93$ & $-0,56$ & $-0,46$ & $-0,66$ & $-0,57$ & $-0,19$ & $-0,29$ & $10 \% / 90 \%$ & & \\
\hline Difference & 0,26 & 0,46 & 0,86 & 0,44 & $-0,34$ & $-1,80$ & $-0,49$ & $-1,71^{* * *}$ & $-0,47$ & $-0,28$ & $-0,29$ & 0,14 & & & \\
\hline \multicolumn{14}{|c|}{ Average } & \multirow{5}{*}{\multicolumn{2}{|c|}{$\begin{array}{c}\text { Excluding } \\
2004-2006 \\
\text { consolidations }\end{array}$}} \\
\hline All & 4,96 & 4,86 & $-0,53$ & $-5,41$ & $-1,10$ & $-2,60$ & $-0,79$ & $-0,84$ & $-0,94$ & $-0,73$ & $-0,19$ & $-0,46$ & $-3 \% / 103 \%$ & & \\
\hline Successful & 5,35 & 5,45 & $-2,20$ & $-7,70$ & $-2,95$ & $-5,20$ & $-1,50$ & $-1,85$ & $-1,60$ & $-1,55$ & $-0,25$ & $-0,30$ & $-54 \% / 154 \%$ & & \\
\hline Unsuccessful & 4,80 & 4,62 & 0,14 & $-4,50$ & $-0,36$ & $-1,56$ & $-0,50$ & $-0,44$ & $-0,68$ & $-0,40$ & $-0,16$ & $-0,52$ & $18 \% / 82 \%$ & & \\
\hline Difference & 0,55 & 0,83 & $-2,34$ & $-3,20$ & $-2,59$ & $-3,64^{* *}$ & $-1,00^{*}$ & $-1,41^{* * *}$ & $-0,92$ & $-1,15$ & $-0,09$ & 0,22 & & & \\
\hline \multicolumn{14}{|c|}{ Average } & \multirow{3}{*}{\multicolumn{2}{|c|}{$\begin{array}{c}2004-2006 \\
\text { consolidations only }\end{array}$}} \\
\hline All & 5,30 & 5,28 & 1,75 & $-3,53$ & 0,25 & $-2,55$ & $-0,65$ & $-1,27$ & $-0,63$ & $-0,58$ & $-0,48$ & 0,15 & $30 \% / 70 \%$ & & \\
\hline \begin{tabular}{|l|} 
Difference \\
from pre 2004 \\
consolidations
\end{tabular} & 0,34 & 0,42 & 2,28 & 1,89 & 1,35 & 0,05 & 0,14 & $-0,42$ & 0,32 & 0,15 & $-0,29$ & 0,61 & & & \\
\hline \multicolumn{16}{|c|}{ 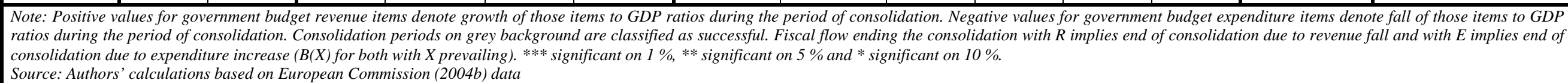 } \\
\hline
\end{tabular}


Interesting differences arise between periods of successful and unsuccessful consolidations. Successful consolidations we were able to identify were associated with considerable government expenditure reduction and took place despite the drop in government revenues. As a result of large decrease of expenditure, those countries that managed to bring about successful consolidation experienced reduction in both ordinary and primary budget deficit exceeding the reduction in the case of unsuccessful consolidations.

Contrary to successful consolidations, the unsuccessful ones has relied less on government expenditure reduction and were associated with slight revenue increases. Unsuccessful consolidation too resulted in reduction of ordinary and primary budget deficit, however on a smaller scale.

Table 3 also reveals the fact that successful consolidations are associated with more pronounced reduction in government expenditure for provision of public good and redistribution, i.e. are based on reduction of those expenditure items that are more politically costly to reduce. Our findings thus support the idea that consolidations based on expenditure reduction as opposed to revenue increases and consolidations based on tackling politically sensitive expenditure items are those that lead to lasting deficit reduction. Although our results do not seem overwhelmingly statistically significant, they point to the direction found by Hagen, Hallett and Strauch (2001) for fiscal adjustment periods in OECD countries in 1960 through 1990 period.

Where our findings differ from findings of Hagen, Hallett and Strauch (2001) is that they found higher reduction in expenditure for public investment during periods of successful consolidations while our data show that less pronounced reduction of this budget item has been associated with successful consolidations in NMSs.

Interesting differences also arise when comparing pre and post EU accession periods of fiscal adjustments. As opposed to pre-EU accession consolidations, post-EU accession consolidations rely more on revenue increases and less on expenditure reductions, despite the fact that post-EU accession consolidations on average aim for more distinct reduction of ordinary and primary budget deficits. Although in general not statistically significant, expenditure items that has been reduced more during pre-EU accession consolidations are collective consumption, social transfers of both kinds and expenditure for public investment. On the other hand, it can be expected that post-EU accession consolidation will be marked by considerable reduction in public employees' wage bill and with reduction in subsidies, which in case of employees' remuneration corroborates our earlier findings about considerable drop of growth of this budget item in EDP countries.

On the whole, it can be said that post-EU accession consolidations induced, among other factors, by non-compliance with the SGP tend to rely on measures, which have been associated with unsuccessful rather than successful consolidations.

\section{CONCLUSION}

As a summary, during the description of fiscal policy in NMSs, we have seen that a lot has been accomplished. Many NMSs implemented important reforms over the past years, from longer perspective, probably most important being pension systems reforms. But also 
many important steps remain to be done. Apart from rather slow progress in health care system reforms in many countries, there seems to be a need to reduce generosity of social benefit systems that repeatedly put a strong pressure on public finance in many NMSs and have been a source of unexpected budgetary developments. Many reforms also display low quality of implementation burdened, above all, by political disputes.

Our analysis confirms that fiscal policy may and does differ within the NMSs. We have identified two groups of countries where one is characterised by a lower share of government and, also, by a low budget deficits. The other group has a higher government share in the economy and runs haphazard fiscal policy characterised by high and persistent fiscal deficits. As it happens, the low government and low deficit group has also experienced higher economic growth, confirming that high government expenditures financed with high deficits do not provide for a sustainable economic growth.

Measures implemented just before or after EDP initiation show clear focus on bringing budget deficits under control, however seem to rely on steps that might be hard to sustain politically as well as on steps that are possible to implement quickly, missing long-term perspective of coherent and comprehensive reforms.

With regard to the political economy issues, more concretely power of MFs in NMSs played key role in determining budget deficit behaviour prior to EU accession. Only economic variable we found to be important for budget deficits in NMSs is effect of restricted exchange rate combined with increasing external imbalance.

Last, and most speculatively, we try to extrapolate experience of "old EU members", i.e. EUR-15 as their fiscal policy in the run up to the EMU membership is concerned. The prized EMU membership had inspired EUR-15 governments to eliminate their deficits and even run an aggregate fiscal surplus, the first and perhaps the last, of $1 \%$ of GDP in year 2000. However, once within the club, EUR-15 has loosened their policies again. ${ }^{18}$ The aggregate government deficit of the twelve eurozone members reached 2,8\% of GDP in 2003 and $2,7 \%$ in 2004. Hallett, Lewis and Hagen (2004) maintain that current fiscal problems of several EUR-15 countries are caused by expansionary fiscal policies during the period of benign economic growth of 2000 and 2001.

The NMS are bound to adopt common European currency sooner or later, so their position is similar to the EUR-15 some 8 years ago and the threat of not being allowed to adopt euro might work as a disciplining tool. However, it seems that the NMS are more resistant to the threat than the EUR-15 were.

The chart 10 draws paths of average budget deficit of EUR-15 and NMSs. Horizontal axis denotes time, with time zero being two years prior to

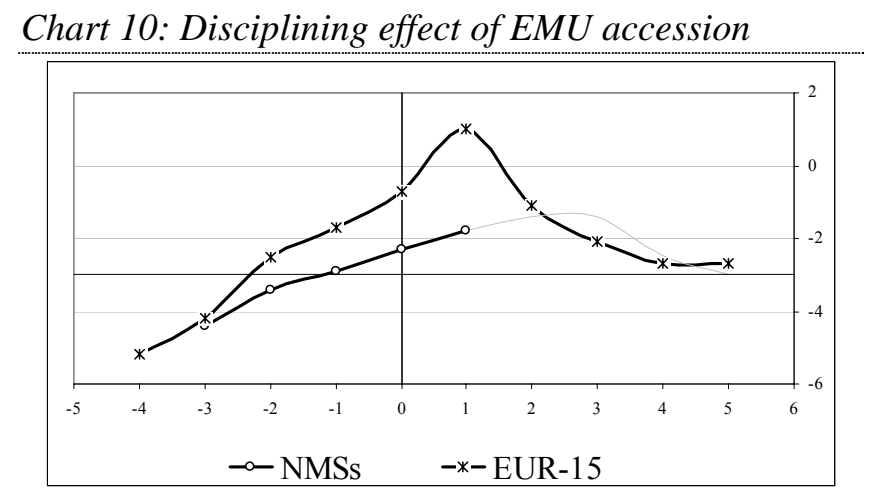

Note: Time zero denotes two years prior to EMU accession, for EUR-15 1999 and for NMSs 2006.

Source: European Commission (2004b); Authors' calculations

${ }^{18}$ Strictly speaking, three of the EUR-15 countries (UK, Sweden and Denmark) are not members of the eurozone. However, even their fiscal polices are subject to the SGP surveillance. 
the euro adoption as these data are most relevant for the accession decision. In case of EUR15, time zero corresponds to year 1999 and in case of NMSs, time zero corresponds to year $2006 .{ }^{19}$

The chart illustrates our earlier point, i.e. that budget deficits in the EUR-15 have widened after the threat of not qualify for euro passed away. The NMSs' fiscal outlook is rather worrying in this context. The NMSs adopted much more relaxed fiscal plans: on average, the NMSs expect to run deficit of about $2 \%$ of GDP in 2006. That means that the NMS will have much smaller margin for fiscal policy relaxation. Given the NMSs' problems in managing fiscal policy and their inclination to run pro-cyclical fiscal policies, odds are not very promising. Moreover, if the NMSs do qualify for the EMU membership, political will to keep fiscal deficits under control may fade as it did in the EUR-15 countries and then the NMSs may face high deficits again.

We believe that the two latter effects, i.e. the tendency of postponing structural reforms and potential malaise following the expected EMU membership, may make for a dangerous brew, especially in the already troubled EDP countries. These six countries (perhaps with the exception of Slovakia) demonstrate their failure to put fiscal policy in order even at time of exceptionally supportive environment: growth is relatively robust and the countries are motivated by cherished EMU membership. Still, they run fiscal deficits averaging $4 \%$ of GDP. One may just fear how high these deficits may become in a few years time...

${ }^{19}$ Although specific year of euro adoption of each NMS is not known yet, we believe year 2008 approximates closely year when NMSs will adopt common European currency on average. 


\section{REFERENCES}

- Alesina, A. and Perotti, R., (1997) "Fiscal Adjustments in OECD Countries: Composition and Macroeconomic Effects”, IMF staff papers, vol.44, no.2., 1997, 210-248.

- Canzoneri, M.B., Cumby, R.E. and Diba, B.T., (2001) "Fiscal Discipline and Exchange Rate Systems", The Economic Journal, vol.111, no.474, 2001, 667-690.

- European Commission, (2004a) "Public Finances in EMU 2004", European Commission, Brussels, European Economy Reports and Studies, no.3, 2004.

- European Commission, (2004b) "General Government Data, Part II: Table by Series, Autumn 2004“, European Commission, Brussels, 2004.

- European Commission, (2004c) "Structures of the Taxation Systems in the European Union, 2004 edition", European Commission, Brussels, 2004.

- Fatas, A. and Rose, A.K., (2001) "Do Monetary Handcuffs Restrain Leviathan? Fiscal Policy in Extreme Exchange Rate Regimes”, IMF staff papers, vol.47, 2001, 40-61.

- Gleich, H., (2002) "The Evolution of Budget Institutions in Central and Eastern European Countries", Ph.D. Thesis, University of Bonn, Bonn, 2002.

- Gleich, H., (2003) "Budget Institutions and Fiscal Performance in Central and Eastern European Countries", ECB working paper, no.215, 2003.

- Gregor, M., (2004) "Governing Fiscal Commons in the Enlarged EU“, Proceedings of conference "Development of Czech Society in EU" organized by Charles University, Prague, $21^{\text {st }}-23^{\text {rd }}$ September, 2004.

- Hagen, von J. and Harden, I.J., (1992) "Budgeting Procedures and Fiscal Performance in the European Countries", European Commission, Brussels, Economic papers, no.96, 1992.

- Hagen, von J., Hallett, A.H. and Strauch, R., (2001) "Budgetary Consolidations in EMU”, European Commission, Brussels, Economic papers, no.148, 2001.

- Hallerberg, M., Strauch, R. and Hagen, von J., (2001) "The Use and Effectiveness of Budgetary Rules and Norms in EU Member States“, Report Prepared for the Dutch Ministry of Finance by the Institute of European Integration Studies, 2001.

- Hallerberg, M., Strauch, R. and Hagen, von J., (2004) "The Design of Fiscal Rules and Forms of Governance in European Union Countries“, ECB working paper, no.419, 2004.

- Hallett, A.H., Lewis, J. and Hagen, von J., (2004) "Fiscal Policy in Europe 1991-2003: An Evidence-based Analysis“, CEPR, 2004.

- McDermott, J.C. and Wescott, R.F., (1996) "An Empirical Analysis of Fiscal Adjustments“, IMF staff papers, vol.43, no.4, 1996, 725-753.

- $\quad$ Orban, G. and Szapary, G., (2004) "The Stability and Growth Pact from the Perspective of the New Member States", William Davidson Institute working paper, no.709, 2004.

- Perotti, R., Strauch, R. and Hagen, von J., (1998), "Sustainable Public Finances", CEPR discussion paper, no.1781, 1997.

- $\quad$ Schneider, O. and Štěpánek, P., (2001) “A Looming Fiscal Crisis in the Czech Republic", in: Dabrowski, M. and Rostowski, J., (eds.), "The Eastern Enlargement of the EU, 1. edition”, Kluwer Academic Publishers, Boston, 2001, 151-168.

- $\quad$ Schneider, O. and Drábek, Z., (2000) "Size of the Public Sector, Contingent Liabilities, and Structural and Cyclical Deficits in the Czech Republic, 1993-1999”, Post-Soviet Geography and Economics, vol.41, no.5, 2000, 311-340.

- $\quad$ Sun, Y., (2003) “Do Fixed Exchange Rates Induce More Fiscal Discipline?", IMF working paper, no.78, 2003.

- Ylaoutinen, S., (2004) "Fiscal Frameworks in the Central and Eastern European Countries", Finish Ministry of finance discussion paper, no.72, 2004. 


\section{APPENDIX}

\begin{tabular}{|c|c|c|c|c|c|c|c|c|c|c|c|c|c|c|c|}
\hline \multicolumn{16}{|c|}{ ESA 1995} \\
\hline \multicolumn{16}{|c|}{ (Percentage of GDP at market prices (excessive deficit procedure)) } \\
\hline & $\mathrm{CY}$ & $\mathrm{CZ}$ & $\mathrm{EE}$ & LV & LT & $\mathrm{HU}$ & MT & PL & SI & SK & Average & EUR-15 & EDP & non EDP & Difference \\
\hline 1995 & $:$ & 41,0 & 43,9 & 37,3 & 34,2 & : & $:$ & 47,4 & : & 53,3 & 42,9 & 46,1 & 47,2 & 38,5 & $8,8 \quad *$ \\
\hline 1996 & : & 39,7 & 40,4 & 37,0 & 34,3 & : & : & 46,5 & : & 54,1 & 42,0 & 46,7 & 46,8 & 37,2 & 9,5 \\
\hline 1997 & $:$ & 40,0 & 40,9 & 38,3 & 37,1 & $:$ & $:$ & 45,7 & $:$ & 58,8 & 43,5 & 46,8 & 48,2 & 38,8 & 9,4 \\
\hline 1998 & 34,3 & 38,8 & 38,9 & 40,6 & 37,4 & $:$ & $:$ & 44,5 & $:$ & 57,1 & 41,7 & 46,6 & 43,7 & 39,0 & 4,7 \\
\hline 1999 & 34,2 & 39,2 & 38,8 & 37,4 & 37,3 & $:$ & $:$ & 44,9 & $:$ & 49,8 & 40,2 & 47,0 & 42,0 & 37,8 & 4,2 \\
\hline 2000 & 36,3 & 38,5 & 37,7 & 35,1 & 35,8 & 44,6 & 35,6 & 42,5 & 44,7 & 47,6 & 39,8 & 46,7 & 40,9 & 38,3 & 2,5 \\
\hline 2001 & 38,0 & 39,1 & 37,2 & 34,4 & 33,0 & 44,3 & 37,4 & 43,8 & 45,1 & 45,5 & 39,8 & 46,2 & 41,4 & 37,4 & 3,9 \\
\hline 2002 & 37,3 & 40,2 & 38,0 & 33,1 & 32,8 & 43,4 & 39,7 & 43,9 & 45,7 & 45,2 & 39,9 & 45,5 & 41,6 & 37,4 & 4,2 \\
\hline 2003 & 39,7 & 41,9 & 38,9 & 34,5 & 32,3 & 43,6 & 39,8 & 43,7 & 46,2 & 35,4 & 39,6 & 45,8 & 40,7 & 38,0 & 2,7 \\
\hline $2004^{(\mathrm{e})}$ & 40,4 & 41,9 & 39,3 & 34,0 & 33,2 & 43,3 & 47,3 & 45,6 & 45,3 & 34,4 & 40,5 & 45,3 & 42,2 & 38,0 & 4,2 \\
\hline $2005^{(\mathrm{f})}$ & 41,4 & 41,6 & 39,6 & 35,3 & 33,7 & 42,5 & 46,7 & 45,7 & 44,6 & 34,3 & 40,5 & 45,2 & 42,0 & 38,3 & 3,7 \\
\hline $2006^{(\mathrm{f})}$ & 41,4 & 41,5 & 39,0 & 34,8 & 33,2 & 42,0 & 45,9 & 45,2 & 44,3 & 33,7 & 40,1 & 45,0 & 41,6 & 37,8 & 3,8 \\
\hline
\end{tabular}

Source: GENERAL GOVERNMENT DATA, EUROPEAN COMMISSION, DIRECTORATE GENERAL ECFIN, ECONOMIC AND FINANCIAL AFFAIRS, PART II: TABLES BY

SERIES, AUTUMN 2004. Note: ${ }^{* * *}$ significant on $1 \%$, ** significant on $5 \%$ and $*$ significant on $10 \%$. ${ }^{(\mathrm{e})}$ denotes expected and ${ }^{(\mathrm{f})}$ forecasted value. 


\begin{tabular}{|c|c|c|c|c|c|c|c|c|c|c|c|c|c|c|c|c|}
\hline \multicolumn{17}{|c|}{ ESA 1995} \\
\hline \multicolumn{17}{|c|}{ (Percentage of GDP at market prices (excessive deficit procedure)) } \\
\hline & $\mathrm{CY}$ & $\mathrm{CZ}$ & $\mathrm{EE}$ & $\mathrm{LV}$ & $\mathrm{LT}$ & $\mathrm{HU}$ & MT & $\mathrm{PL}$ & SI & SK & Average & EUR-15 & EDP & non EDP & Difference & \\
\hline 1995 & $:$ & 54,4 & 43,4 & 39,3 & 36,1 & $:$ & $:$ & 51,3 & $:$ & 54,1 & 46,4 & 51,3 & 53,3 & 39,6 & $13,7^{* * *}$ & *** \\
\hline 1996 & $:$ & 42,8 & 42,1 & 37,4 & 37,9 & $:$ & $:$ & 51,2 & $:$ & 61,5 & 45,5 & 50,9 & 51,8 & 39,1 & 12,7 & $*$ \\
\hline 1997 & $:$ & 42,4 & 39,2 & 36,8 & 38,3 & $:$ & $:$ & 50,2 & $:$ & 65,0 & 45,3 & 49,3 & 52,5 & 38,1 & 14,4 & \\
\hline 1998 & 38,6 & 43,8 & 39,3 & 41,3 & 40,4 & $:$ & $:$ & 46,6 & $:$ & 60,8 & 44,4 & 48,2 & 47,5 & 40,3 & 7,1 & \\
\hline 1999 & 38,7 & 42,9 & 42,6 & 42,3 & 42,9 & $:$ & $:$ & 47,0 & $:$ & 56,9 & 44,8 & 47,7 & 46,4 & 42,6 & 3,8 & \\
\hline 2000 & 38,7 & 42,1 & 38,2 & 37,9 & 38,4 & 47,6 & 41,9 & 44,2 & 48,2 & 59,9 & 43,7 & 45,8 & 45,7 & 40,7 & 5,1 & \\
\hline 2001 & 40,4 & 45,0 & 36,9 & 36,5 & 35,0 & 48,7 & 43,8 & 47,7 & 47,9 & 51,5 & 43,3 & 47,2 & 46,2 & 39,1 & 7,1 & * \\
\hline 2002 & 41,9 & 46,9 & 36,6 & 35,8 & 34,3 & 52,6 & 45,5 & 48,1 & 48,1 & 50,9 & 44,1 & 47,6 & 47,7 & 38,7 & 9,0 & ** \\
\hline 2003 & 46,1 & 54,5 & 35,8 & 36,0 & 34,1 & 49,8 & 49,4 & 47,6 & 48,2 & 39,2 & 44,1 & 48,5 & 47,8 & 38,5 & 9,2 & ** \\
\hline $2004^{(\mathrm{e})}$ & 45,6 & 46,7 & 38,8 & 36,0 & 35,7 & 48,7 & 52,4 & 51,3 & 47,5 & 38,3 & 44,1 & 48,0 & 47,2 & 39,5 & 7,7 & ** \\
\hline $2005^{(\mathrm{f})}$ & 44,4 & 46,3 & 39,4 & 38,1 & 36,2 & 47,6 & 50,7 & 49,9 & 46,8 & 38,3 & 43,8 & 47,5 & 46,2 & 40,1 & 6,1 & ** \\
\hline $2006^{(\mathrm{f})}$ & 43,9 & 45,8 & 38,9 & 37,7 & 35,1 & 46,7 & 49,2 & 48,3 & 46,3 & 37,9 & 43,0 & 47,3 & 45,3 & 39,5 & 5,8 & * \\
\hline
\end{tabular}




\begin{tabular}{|c|c|c|c|c|c|c|c|c|c|c|c|c|c|c|c|}
\hline \multicolumn{16}{|c|}{ ESA 1995} \\
\hline \multicolumn{16}{|c|}{ (Percentage of GDP at market prices (excessive deficit procedure)) } \\
\hline & $\mathrm{CY}$ & $\mathrm{CZ}$ & $\mathrm{EE}$ & LV & $\mathrm{LT}$ & $\mathrm{HU}$ & MT & PL & SI & SK & Average & EUR-15 & EDP & non EDP & Difference \\
\hline 1995 & : & $-13,4$ & 0,4 & $-2,0$ & $-1,9$ & : & : & $-2,3$ & $:$ & $-0,9$ & $-3,4$ & $-5,2$ & $-5,5$ & \begin{tabular}{|l|l}
$-1,2$ &
\end{tabular} & $-4,4$ \\
\hline 1996 & : & $-3,1$ & $-1,7$ & $-0,5$ & $-3,6$ & : & : & $-3,6$ & : & $-7,4$ & $-3,3$ & $-4,2$ & $-4,7$ & $-1,9$ & $-2,8$ \\
\hline 1997 & $:$ & $-2,4$ & 1,7 & 1,5 & $-1,2$ & : & : & $-4,0$ & : & $-6,2$ & $-1,8$ & $-2,5$ & $-4,2$ & 0,7 & $-4,9$ \\
\hline 1998 & $-4,3$ & $-5,0$ & $-0,3$ & $-0,6$ & $-3,0$ & $:$ & $:$ & $-2,1$ & $:$ & $-3,8$ & $-2,7$ & $-1,7$ & $-3,8$ & $-1,3$ & $-2,5$ \\
\hline 1999 & $-4,5$ & $-3,6$ & $-3,7$ & $-4,9$ & $-5,6$ & $:$ & : & $-1,4$ & : & $-7,1$ & $-4,4$ & $-0,7$ & $-4,2$ & $-4,7$ & 0,6 \\
\hline 2000 & $-2,4$ & $-3,7$ & $-0,6$ & $-2,8$ & $-2,5$ & $-3,0$ & $-6,2$ & $-0,7$ & $-3,5$ & $-12,3$ & $-3,8$ & 1,0 & $-4,7$ & $-2,4$ & $-2,4$ \\
\hline 2001 & $-2,4$ & $-5,9$ & 0,3 & $-2,1$ & $-2,0$ & $-4,4$ & $-6,4$ & $-3,8$ & $-2,8$ & $-6,0$ & $-3,6$ & $-1,1$ & $-4,8$ & $-1,7$ & $-3,2$ \\
\hline 2002 & $-4,6$ & $-6,8$ & 1,4 & $-2,7$ & $-1,5$ & $-9,2$ & $-5,8$ & $-3,6$ & $-2,4$ & $-5,7$ & $-4,1$ & $-2,1$ & $-6,0$ & $-1,3$ & $-4,7$ \\
\hline 2003 & $-6,4$ & $-12,6$ & 3,1 & $-1,5$ & $-1,9$ & $-6,2$ & $-9,6$ & $-3,9$ & $-2,0$ & $-3,7$ & $-4,5$ & $-2,7$ & $-7,1$ & $-0,6$ & $-6,5$ \\
\hline $2004^{(\mathrm{e})}$ & $-5,2$ & $-4,8$ & 0,5 & $-2,0$ & $-2,6$ & $-5,5$ & $-5,1$ & $-5,6$ & $-2,3$ & $-3,9$ & $-3,7$ & $-2,7$ & $-5,0$ & $-1,6$ & $-3,4$ \\
\hline $2005^{(\mathrm{f})}$ & $-3,0$ & $-4,7$ & 0,2 & $-2,8$ & $-2,5$ & $-5,2$ & $-4,0$ & $-4,1$ & $-2,2$ & $-4,0$ & $-3,2$ & $-2,4$ & $-4,2$ & $-1,8$ & $-2,3$ \\
\hline $2006^{(\mathrm{f})}$ & $-2,4$ & $-4,3$ & 0,1 & $-2,9$ & $-1,9$ & $-4,7$ & $-3,3$ & $-3,1$ & $-1,9$ & $-4,1$ & $-2,9$ & $-2,3$ & $-3,7$ & $-1,7$ & $-2,0$ \\
\hline
\end{tabular}




\begin{tabular}{|c|c|c|c|c|c|c|c|c|c|c|c|c|c|c|c|c|}
\hline \multicolumn{17}{|c|}{ ESA 1995} \\
\hline \multicolumn{17}{|c|}{ (Percentage of GDP at market prices (excessive deficit procedure)) } \\
\hline & $\mathrm{CY}$ & $\mathrm{CZ}$ & $\mathrm{EE}$ & $\mathrm{LV}$ & $\mathrm{LT}$ & $\mathrm{HU}$ & MT & PL & SI & SK & Average & EUR-15 & EDP & non EDP & Differenc & \\
\hline 1995 & : & : & $:$ & : & : & $:$ & : & : & $:$ & $:$ & : & 70,7 & $:$ & : & $:$ & $:$ \\
\hline 1996 & $:$ & 13,1 & 7,5 & 13,8 & $:$ & 73,6 & 40,0 & $:$ & $:$ & 30,3 & 29,7 & 72,6 & 39,3 & 10,7 & 28,6 & * \\
\hline 1997 & $:$ & 12,7 & 6,3 & 11,1 & 15,8 & 63,9 & 48,1 & $:$ & $:$ & 33,0 & 27,3 & 71,0 & 39,4 & 11,1 & 28,4 & ** \\
\hline 1998 & 61,6 & 15,0 & 5,6 & 9,8 & 16,8 & 61,6 & 53,1 & $:$ & 23,6 & 34,0 & 31,2 & 68,8 & 45,1 & 14,0 & 31,1 & $* *$ \\
\hline 1999 & 62,0 & 16,0 & 6,0 & 12,6 & 23,0 & 60,9 & 56,8 & 40,1 & 24,9 & 47,2 & 35,0 & 67,9 & 47,2 & 16,6 & 30,5 & *** \\
\hline 2000 & 61,6 & 18,2 & 4,7 & 12,9 & 23,8 & 55,4 & 56,4 & 36,8 & 27,4 & 49,9 & 34,7 & 64,1 & 46,4 & 17,2 & 29,2 & \\
\hline 2001 & 64,3 & 25,3 & 4,4 & 14,9 & 22,9 & 53,5 & 62,0 & 36,7 & 28,1 & 48,7 & 36,1 & 63,2 & 48,4 & 17,6 & 30,8 & \\
\hline 2002 & 67,4 & 28,8 & 5,3 & 14,1 & 22,4 & 57,2 & 62,3 & 41,1 & 29,5 & 43,3 & 37,1 & 62,7 & 50,0 & 17,8 & 32,2 & \\
\hline 2003 & 70,9 & 37,8 & 5,3 & 14,4 & 21,4 & 59,1 & 70,4 & 45,4 & 29,4 & 42,6 & 39,7 & 64,2 & 54,4 & 17,6 & 36,7 & \\
\hline $2004^{(\mathrm{e})}$ & 72,6 & 37,8 & 4,8 & 14,6 & 21,1 & 59,7 & 72,4 & 47,7 & 30,9 & 44,2 & 40,6 & 64,4 & 55,7 & 17,9 & 37,9 & \\
\hline $2005^{(\mathrm{f})}$ & 72,4 & 39,4 & 4,4 & 15,4 & 21,7 & 59,5 & 73,7 & 49,8 & 30,8 & 45,2 & 41,2 & 64,5 & 56,7 & 18,1 & 38,6 & \\
\hline $2006^{(\mathrm{f})}$ & 69,4 & 40,6 & 4,2 & 16,6 & 21,3 & 58,9 & 74,2 & 49,3 & 30,6 & 45,9 & 41,1 & 64,3 & 56,4 & 18,2 & 38,2 & \\
\hline
\end{tabular}




\section{CESifo Working Paper Series}

(for full list see www.cesifo-group.de)

1421 Giorgio Bellettini and Carlotta Berti Ceroni, When the Union Hurts the Workers: A Positive Analysis of Immigration Policy, March 2005

1422 Pieter Gautier, Michael Svarer and Coen Teulings, Marriage and the City, March 2005

1423 Ingrid Ott and Stephen J. Turnovsky, Excludable and Non-Excludable Public Inputs: Consequences for Economic Growth, March 2005

1424 Frederick van der Ploeg, Back to Keynes?, March 2005

1425 Stephane Dees, Filippo di Mauro, M. Hashem Pesaran and L. Vanessa Smith, Exploring the International Linkages of the Euro Area: a Global VAR Analysis, March 2005

1426 Hans Pitlik, Friedrich Schneider and Harald Strotmann, Legislative Malapportionment and the Politicization of Germany's Intergovernmental Transfer System, March 2005

1427 Konstantinos Angelopoulos and Apostolis Philippopoulos, The Role of Government in Anti-Social Redistributive Activities, March 2005

1428 Ansgar Belke and Daniel Gros, Asymmetries in the Trans-Atlantic Monetary Policy Relationship: Does the ECB follow the Fed?, March 2005

1429 Sören Blomquist and Luca Micheletto, Optimal Redistributive Taxation when Government's and Agents' Preferences Differ, March 2005

1430 Olof Åslund and Peter Fredriksson, Ethnic Enclaves and Welfare Cultures - QuasiExperimental Evidence, March 2005

1431 Paul De Grauwe, Roberto Dieci and Marianna Grimaldi, Fundamental and NonFundamental Equilibria in the Foreign Exchange Market. A Behavioural Finance Framework, March 2005

1432 Peter Egger, Stefan Gruber, Mario Larch and Michael Pfaffermayr, Knowledge-Capital Meets New Economic Geography, March 2005

1433 George Economides and Apostolis Philippopoulos, Should Green Governments Give Priority to Environmental Policies over Growth-Enhancing Policies?, March 2005

1434 George W. Evans and Seppo Honkapohja, An Interview with Thomas J. Sargent, March 2005

1435 Helge Berger and Volker Nitsch, Zooming Out: The Trade Effect of the Euro in Historical Perspective, March 2005 
1436 Marc-Andreas Muendler, Rational Information Choice in Financial Market Equilibrium, March 2005

1437 Martin Kolmar and Volker Meier, Intra-Generational Externalities and InterGenerational Transfers, March 2005

1438 M. Hashem Pesaran and Takashi Yamagata, Testing Slope Homogeneity in Large Panels, March 2005

1439 Gjermund Nese and Odd Rune Straume, Industry Concentration and Strategic Trade Policy in Successive Oligopoly, April 2005

1440 Tomer Blumkin and Efraim Sadka, A Case for Taxing Education, April 2005

1441 John Whalley, Globalization and Values, April 2005

1442 Denise L. Mauzerall, Babar Sultan, Namsoug Kim and David F. Bradford, Charging $\mathrm{NO}_{x}$ Emitters for Health Damages: An Exploratory Analysis, April 2005

1443 Britta Hamburg, Mathias Hoffmann and Joachim Keller, Consumption, Wealth and Business Cycles in Germany, April 2005

1444 Kohei Daido and Hideshi Itoh, The Pygmalion Effect: An Agency Model with Reference Dependent Preferences, April 2005

1445 John Whalley, Rationality, Irrationality and Economic Cognition, April 2005

1446 Henning Bohn, The Sustainability of Fiscal Policy in the United States, April 2005

1447 Torben M. Andersen, Is there a Role for an Active Fiscal Stabilization Policy? April 2005

1448 Hans Gersbach and Hans Haller, Bargaining Power and Equilibrium Consumption, April 2005

1449 Jerome L. Stein, The Transition Economies: A NATREX Evaluation of Research, April 2005

1450 Raymond Riezman, John Whalley and Shunming Zhang, Metrics Capturing the Degree to which Individual Economies are Globalized, April 2005

1451 Romain Ranciere, Aaron Tornell and Frank Westermann, Systemic Crises and Growth, April 2005

1452 Plutarchos Sakellaris and Focco W. Vijselaar, Capital Quality Improvement and the Sources of Growth in the Euro Area, April 2005

1453 Kevin Milligan and Michael Smart, Regional Grants as Pork Barrel Politics, April 2005 
1454 Panu Poutvaara and Andreas Wagener, To Draft or not to Draft? Efficiency, Generational Incidence, and Political Economy of Military Conscription, April 2005

1455 Maurice Kugler and Hillel Rapoport, Skilled Emigration, Business Networks and Foreign Direct Investment, April 2005

1456 Yin-Wong Cheung and Eiji Fujii, Cross-Country Relative Price Volatility: Effects of Market Structure, April 2005

1457 Margarita Katsimi and Thomas Moutos, Inequality and Relative Reliance on Tariffs: Theory and Evidence, April 2005

1458 Monika Bütler, Olivia Huguenin and Federica Teppa, Why Forcing People to Save for Retirement may Backfire, April 2005

1459 Jos Jansen, The Effects of Disclosure Regulation of an Innovative Firm, April 2005

1460 Helge Bennmarker, Kenneth Carling and Bertil Holmlund, Do Benefit Hikes Damage Job Finding? Evidence from Swedish Unemployment Insurance Reforms, May 2005

1461 Steffen Huck, Kai A. Konrad and Wieland Müller, Merger without Cost Advantages, May 2005

1462 Louis Eeckhoudt and Harris Schlesinger, Putting Risk in its Proper Place, May 2005

1463 Hui Huang, John Whalley and Shunming Zhang, Trade Liberalization in a Joint Spatial Inter-Temporal Trade Model, May 2005

1464 Mikael Priks, Optimal Rent Extraction in Pre-Industrial England and France - Default Risk and Monitoring Costs, May 2005

1465 François Ortalo-Magné and Sven Rady, Heterogeneity within Communities: A Stochastic Model with Tenure Choice, May 2005

1466 Jukka Pirttilä and Sanna Tenhunen, Pawns and Queens Revisited: Public Provision of Private Goods when Individuals make Mistakes, May 2005

1467 Ernst Fehr, Susanne Kremhelmer and Klaus M. Schmidt, Fairness and the Optimal Allocation of Ownership Rights, May 2005

1468 Bruno S. Frey, Knight Fever - Towards an Economics of Awards, May 2005

1469 Torberg Falch and Marte Rønning, The Influence of Student Achievement on Teacher Turnover, May 2005

1470 John Komlos and Peter Salamon, The Poverty of Growth with Interdependent Utility Functions, May 2005 
1471 Hui Huang, Yi Wang, Yiming Wang, John Whalley and Shunming Zhang, A Trade Model with an Optimal Exchange Rate Motivated by Current Discussion of a Chinese Renminbi Float, May 2005

1472 Helge Holden, Lars Holden and Steinar Holden, Contract Adjustment under Uncertainty, May 2005

1473 Kai A. Konrad, Silent Interests and All-Pay Auctions, May 2005

1474 Ingo Vogelsang, Electricity Transmission Pricing and Performance-Based Regulation, May 2005

1475 Spiros Bougheas and Raymond Riezman, Trade and the Distribution of Human Capital, June 2005

1476 Vesa Kanniainen, Seppo Kari and Jouko Ylä-Liedenpohja, The Start-Up and Growth Stages in Enterprise Formation: The "New View" of Dividend Taxation Reconsidered, June 2005

1477 M. Hashem Pesaran, L. Vanessa Smith and Ron P. Smith, What if the UK had Joined the Euro in 1999? An Empirical Evaluation Using a Global VAR, June 2005

1478 Chang Woon Nam and Doina Maria Radulescu, Effects of Corporate Tax Reforms on SMEs' Investment Decisions under the Particular Consideration of Inflation, June 2005

1479 Panos Hatzipanayotou, Sajal Lahiri and Michael S. Michael, Globalization, CrossBorder Pollution and Welfare, June 2005

1480 John Whalley, Pitfalls in the Use of Ad valorem Equivalent Representations of the Trade Impacts of Domestic Policies, June 2005

1481 Edward B. Barbier and Michael Rauscher, Trade and Development in a Labor Surplus Economy, June 2005

1482 Harrie A. A. Verbon and Cees A. Withagen, Tradable Emission Permits in a Federal System, June 2005

1483 Hendrik Hakenes and Andreas Irmen, On the Long-Run Evolution of Technological Knowledge, June 2005

1484 Nicolas Schmitt and Antoine Soubeyran, A Simple Model of Brain Circulation, June 2005

1485 Carsten Hefeker, Uncertainty, Wage Setting and Decision Making in a Monetary Union, June 2005

1486 Ondřej Schneider and Jan Zápal, Fiscal Policy in New EU Member States - Go East, Prudent Man!, June 2005 